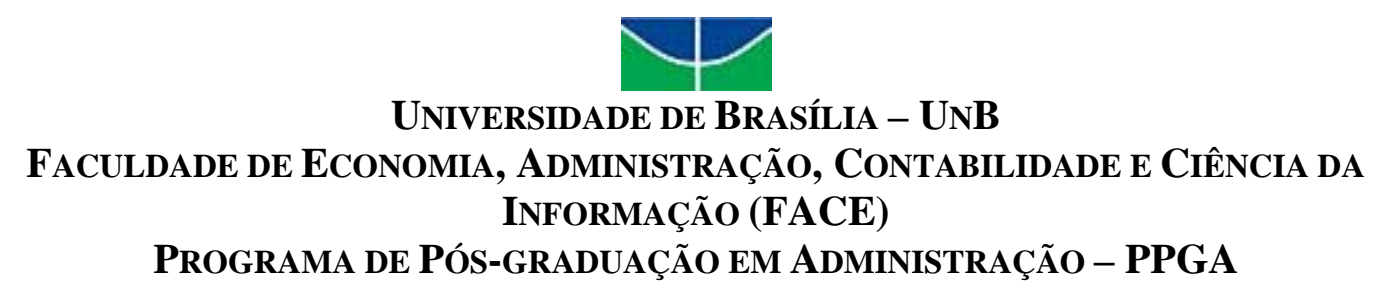

IZABEly Michelle CAVAlCANTE NoRMANDo

\title{
ADMINISTRAÇÃO DE SERVIÇOS PÚBLICOS COM FOCO NO CIDADÃO: UMA AVALIAÇÃO DOS SERVIÇOS PRESTADOS PELOS ÓRGÃOS JULGADORES DO SUPERIOR TRIBUNAL DE JUSTIÇA
}




\section{ADMINISTRAÇÃO DE SERVIÇOS PÚBLICOS COM FOCO NO CIDADÃO: UMA AVALIAÇÃO DOS SERVIÇOS PRESTADOS PELOS ÓRGÃOS JULGADORES DO SUPERIOR TRIBUNAL DE JUSTIÇA}

Monografia apresentada ao Programa de PósGraduação em Administração da Faculdade de Economia, Administração, Contabilidade e Ciência da Informação e Documentação (FACE) da Universidade de Brasília, como requisito parcial à obtenção do grau de Especialista em Gestão Judiciária.

Orientador: Prof ${ }^{\circ}$. Dr. Eduardo Raupp de Vargas 


\section{ADMINISTRAÇÃO DE SERVIÇOS PÚBLICOS COM FOCO NO CIDADÃO: UMA AVALIAÇÃO DOS SERVIÇOS PRESTADOS PELOS ÓRGÃOS JULGADORES DO SUPERIOR TRIBUNAL DE JUSTIÇA}

Monografia apresentada ao Programa de PósGraduação em Administração da Faculdade de Economia, Administração, Contabilidade e Ciência da Informação e Documentação (FACE) da Universidade de Brasília, como requisito parcial à obtenção do grau de Especialista em Gestão Judiciária.

APROVADA POR:

Prof. Dr. Eduardo RAupp de VARgas

ORIENTADOR

PROGRAMA DE PÓS-GRADUAÇÃO EM ADMINISTRAÇÃO - UNIVERSIDADE DE BRASÍLIA 
Dedico este trabalho ao Murilo, meu sempre consciente, bravo e encorajador companheiro. À minha amada mãe, que me ensinou a nunca desistir diante dos problemas. E ao meu pai, por mostrar que é digno voltar e recomeçar. 


\section{AGRADECIMENTOS}

Aos meus eternos colegas de trabalho da Seção de Documentos Judiciários, por dividirem comigo idéias que ajudaram a gerar este trabalho.

À Bárdia Tupy Vieira Fonseca e Cláudia Austregésilo de Athayde Beck, por permitirem e viabilizarem a realização da pesquisa na Secretaria dos Órgãos Julgadores do STJ.

Aos colegas das unidades de atendimento da SOJ, pela disponibilidade em executar a ingrata tarefa de aplicar o instrumento de pesquisa.

Ao Bidu, por nunca me abandonar durante a solitária tarefa de escrever. 


\section{RESUMO}

O presente estudo analisa a qualidade percebida pelos usuários dos serviços dos Órgãos Julgadores do Superior Tribunal de Justiça. A análise desenvolve-se a partir da contextualização do que é qualidade no serviço público, baseando-se na evolução da administração pública no Brasil, e na qualidade como satisfação do cliente-cidadão. Esse encadeamento é realizado com subsídio de textos que abordam a definição de serviços e serviços públicos; as reformas da administração pública brasileira e a administração gerencial; a administração pública voltada para o cidadão; e a cultura da prestação de serviços.

A mensuração da qualidade percebida pelos usuários foi realizada com o auxílio do Instrumento SERVQUAL e analisada com base no modelo de gaps da qualidade A aplicação do instrumento deu-se em todas as unidades de atendimento da SOJ.

A análise dos dados permitiu concluir que os serviços prestados pela Secretaria dos Órgãos Julgadores do Superior Tribunal de Justiça têm boa qualidade e atendem as expectativas dos usuários, ainda que ajustes sejam requeridos. Por isso algumas alterações na dinâmica e na administração dos serviços são sugeridas para que seja atingida a meta de excelência na prestação dos mesmos.

Palavras-chave: Poder Judiciário. Superior Tribunal de Justiça. Administração Pública. Qualidade no Serviço Público. Instrumento SERVQUAL. 


\section{LISTA DE TABELAS}

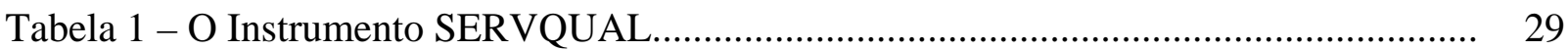

Tabela 2 - Média das respostas - questionário expectativa................................................. 37

Tabela 3 - Média das respostas - questionário percepção.................................................. 39

Tabela 4 - Médias por dimensão da qualidade e gap final................................................... 40

Tabela 5 - Expectativas dos usuários - dimensão aspectos tangíveis................................... 41

Tabela 6 - Percepção dos usuários - dimensão aspectos tangíveis........................................ 43

Tabela 7 - GAPs - dimensão aspectos tangíveis................................................................. 44

Tabela 8 - Expectativas dos usuários - dimensão confiabilidade......................................... 46

Tabela 9 -Percepção dos usuários - dimensão confiabilidade............................................... 47

Tabela 10 - GAPs - dimensão confiabilidade..................................................................... 49

Tabela 11 - Expectativas dos usuários - dimensão presteza................................................. 50

Tabela 12 - Percepção dos usuários - dimensão presteza................................................... 51

Tabela 13 - GAPs - dimensão presteza............................................................................. 53

Tabela 14 - Expectativas dos usuários - dimensão segurança.............................................. 54

Tabela 15 - Percepção dos usuários - dimensão segurança.................................................. 56

Tabela 16 - GAPs - dimensão segurança......................................................................... 57

Tabela 17 - Expectativas dos usuários - dimensão empatia................................................. 58

Tabela 18 - Percepção dos usuários - dimensão empatia..................................................... 59

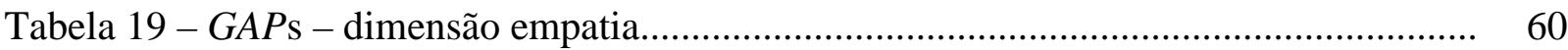

Tabela 20 - Totalização do GAP da qualidade no serviço prestado..................................... 61 


\section{SUMÁRIO}

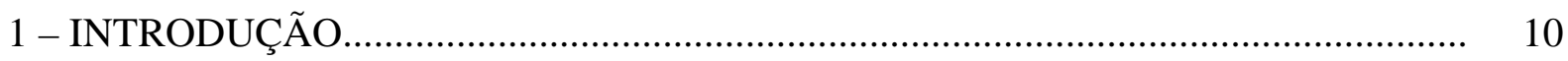

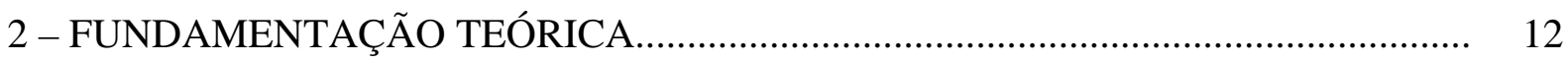

2.1 - O conceito de serviço.................................................................................... 12

2.1.1 - Definição de serviço.................................................................................... 12

2.1.2 - Características dos serviços................................................................. 14

2.1.3 - Tipos de serviços................................................................................... 15

2.1.4 - Serviços públicos..................................................................................... 16

2.2 - Qualidade no serviço público................................................................ 18

2.2.1 - Evolução da administração pública brasileira............................................. 18

2.2.1.1 - O modelo gerencial no Brasil..................................................... 19

2.2.3 - A administração pública voltada para o cidadão....................................... 21

2.2.3.1 - Foco no cidadão: princípios e desenvolvimento conceitual............... 22

2.2.4 - Qualidade como satisfação do cidadão-usuário........................................ 25

2.3 - Instrumento de mensuração da qualidade em serviços........................................ 26

2.3.1 - O instrumento SERVQUAL e o modelo “gap”........................................ 27

2.3.2 - Aplicação do instrumento SERVQUAL no serviço público........................ 31

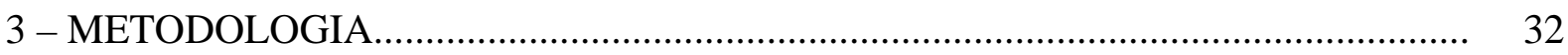

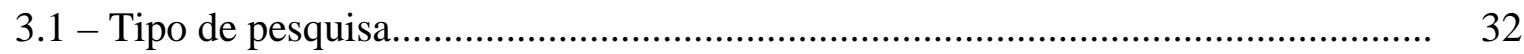

3.2 - Contextualização do ambiente da pesquisa...................................................... 32

3.2.1 - A Secretaria dos Órgãos Julgadores..................................................... 34

3.3 - População e amostra................................................................................. 35

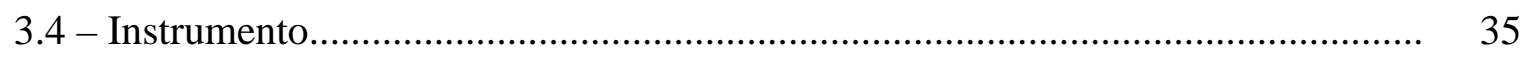

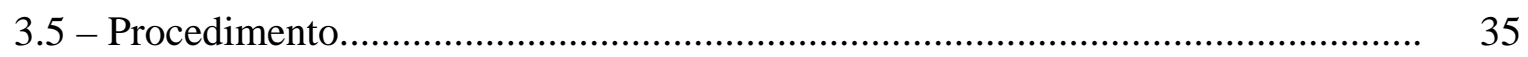

3.6 - Procedimentos de análise de dados.................................................................. 36

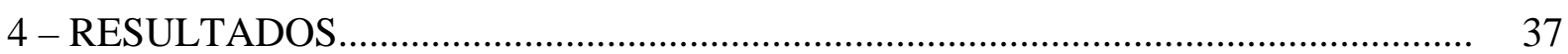

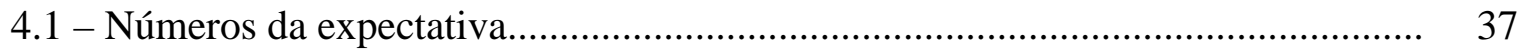


4.2 - Números da percepção................................................................................ 38

4.3 - Números por dimensão da qualidade e gap final.................................................... 40

5 - ANÁLISE DOS RESULTADOS................................................................................ 41

5.1 - Dimensão 1: aspectos tangíveis............................................................................. 41

5.1.1 - Expectativa dos usuários nos aspectos tangíveis.......................................... 41

5.1.2 - Percepção dos usuários nos aspectos tangíveis............................................... 43

5.1.3 - GAP da dimensão aspectos tangíveis............................................................ 44

5.2 - Dimensão 2: confiabilidade............................................................................... 46

5.2.1 - Expectativa dos usuários quanto à confiabilidade......................................... 46

5.2.2 - Percepção dos usuários quanto à confiabilidade........................................... 47

5.2.3 - GAP da dimensão confiabilidade.............................................................. 48

5.3 - Dimensão 3: presteza......................................................................................... 50

5.3.1 - Expectativa dos usuários quanto à presteza................................................. 50

5.3.2 - Percepção dos usuários quanto à presteza.................................................... 51

5.3.3 - GAP da dimensão presteza........................................................................... 53

5.4 - Dimensão 4: segurança.................................................................................... 54

5.4.1 - Expectativa dos usuários quanto à segurança................................................ 54

5.4.2 - Percepção dos usuários quanto à segurança................................................ 55

5.4.3 - GAP da dimensão segurança.................................................................... 56

5.5 - Dimensão 5: empatia......................................................................................... 57

5.5.1 - Expectativa dos usuários quanto à empatia................................................. 57

5.5.2 - Percepção dos usuários quanto à empatia.................................................... 58

5.5.3 - GAP da dimensão empatia........................................................................ 59

5.6 - GAP Total das 5 dimensões - o gap da qualidade do serviç̧o................................ 60

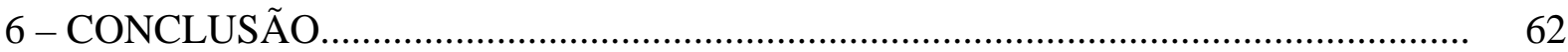

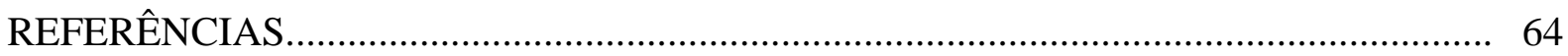




\section{INTRODUÇÃO}

No Brasil, a administração pública passou por três grandes reformas na tentativa de reestruturar e modernizar a máquina do Estado. A primeira, a Reforma Burocrática de 1936, inspirada no modelo descrito por Weber; a segunda foi sistematizada no Decreto-Lei 200, de 1967. Ambas foram idealizadas e implementadas em contextos de ditadura política e sem debate com a sociedade. A terceira, iniciada em 1995, foi a primeira a pensar o setor público do país em um contexto democrático, com ênfase para o atendimento dos seus cidadãos, e com a consideração de que as instituições públicas devem ser eficientes e eficazes e o debate do Estado com a sociedade deve ser incrementado. (BRESSER - PEREIRA, 1998).

Nesta reforma, foi introduzida a noção de serviço público orientado para o cidadão, a qual pode ser considerada uma quebra do paradigma de prestação de serviços até então arraigados no setor público brasileiro. Todavia, essa quebra também trouxe para os administradores públicos a necessidade de conhecer os anseios dos cidadãos para os quais presta seu serviço e assim melhor direcionar suas ações de otimização de recursos e sua capacidade de inovação.

Diante dessas novas necessidades surgiu o problema que motivou a pesquisa sobre a qual disserta esse trabalho: qual a qualidade percebida pelos usuários do Superior Tribunal de Justiça quanto aos serviços prestados pelas unidades que compõem a Secretaria dos Órgãos Julgadores?

O objetivo do trabalho foi mensurar a qualidade percebida pelos usuários do Superior Tribunal de Justiça quanto aos serviços prestados pela Secretaria dos Órgãos Julgadores SOJ. Neste sentido, foram analisados os conceitos de serviço, serviço público e serviço público orientado ao cidadão. Posteriormente discutiu-se a gestão pública no Brasil, seu histórico e suas mais recentes reformas.

Após essas discussões e análises foi aplicado um instrumento (quantitativo) para verificar a qualidade percebida pelos usuários do STJ quanto aos serviços prestados pela SOJ.

Os estudos teóricos e a posterior pesquisa justificaram-se na necessidade latente de o Superior Tribunal de Justiça conhecer, por meio de um instrumento comprovadamente eficiente, a qualidade percebida por seus usuários em relação aos serviços prestados por seus órgãos julgadores. O trabalho motivou-se também pelo fato de que todas as pesquisas de satisfação e qualidade realizadas até então pelo STJ não foram aplicadas com instrumentos cientificamente e academicamente testados, que captem a real percepção dos cidadãos que se utilizam dos seus serviços. 
Fato é que o Poder Judiciário, bem como o serviço público em geral, é carente de trabalhos que visem mensurar a percepção dos seus usuários quanto à qualidade dos serviços prestados aos cidadãos. Sendo assim, o presente trabalho traz uma contribuição inédita dentro do STJ e, conseqüentemente, poderá ser continuado pela instituição no sentido de aprimorar o conhecimento dos seus usuários, auxiliando, então, outros órgãos do mesmo poder a enxergar com clareza sua realidade quanto à qualidade dos serviços prestados.

Salienta-se ainda a importância do presente estudo pelas poucas iniciativas de mensuração e difusão da qualidade nos serviços públicos, tanto no Brasil como nos demais países do mundo. Além disso, o estudo trouxe uma contribuição metodológica para o serviço público brasileiro através da adaptação do instrumento SERVQUAL (avalia a satisfação do cliente através da diferença entre a expectativa do usuário e o desempenho da organização (PARASURAMAN et al, apud ABACKERLI et al, 2005) instrumento concebido para aplicação na iniciativa privada - para a mensuração da qualidade dos serviços prestados numa instituição pública. 


\section{FUNDAMENTAÇÃO TEÓRICA}

A fundamentação teórica que se segue é resultado de um estudo detalhado, dividido em três partes que, articuladas, embasam o estudo realizado no Superior Tribunal de Justiça. A primeira parte traz o conceito de serviço, os elementos que caracterizam o serviço, os tipos de serviço estudados e, ainda, a conceituação e caracterização de serviços públicos. Na segunda parte são apresentados os conceitos da qualidade no serviço público e a evolução da qualidade na administração pública brasileira. Na terceira e última parte é apresentado o instrumento SERVQUAL utilizado para na pesquisa do trabalho, suas bases teóricas e o modelo utilizado para a concepção e aplicação.

\subsection{O conceito de serviço}

A tarefa de conceituar o termo serviço foi, e ainda é, demasiadamente complexa. Uma infinidade de autores já tentou finalizar uma conceituação, contudo ainda só é possível entender de forma real o conceito de serviço quando se busca a essência de vários deles para, assim, obter um melhor entendimento. Os capítulos que se seguem destinam-se a explicitar as definições elaboradas por diversos autores e assim viabilizar um melhor entendimento do termo, bem como sua importância para os serviços públicos.

\subsubsection{Definição de serviço}

Muitas definições de serviços são encontradas, mas todas contêm um tema comum: a intangibilidade e, portanto, a simultaneidade da produção e do consumo. Fitzsimmons e Fitzsimmons (2005) apresentam um rol de conceitos de serviço que se inicia com Valerie A. Zeithamal e Mary Jo Bitner : "Serviços são atos, processos e desempenho de ações” (Services Marketing, McGraw-Hill, New York, 1996, p.5).

A seguir Grönroos (1990) pontua que:

Serviço é uma atividade ou uma série de atividades de natureza mais ou menos intangível que normalmente, mas não necessariamente, ocorre em interações entre consumidores e empregados de serviços e/ou recursos físicos ou bens e/ou sistemas de fornecedor do serviço, que são oferecidos como soluções para os problemas do consumidor. (Christian Gronroos, Marketing, gerenciamento e serviços, Editora Campus, São Paulo, 1993, p. 33)

Seqüencialmente o autor traz a reflexão de três autores:

A maior parte dos experts nessa área considera que o setor de serviços abrange todas as atividades econômicas cujo produto não é um bem físico ou fabricado; geralmente 
ele é consumido no momento em que é produzido e fornece um valor agregado em formas (tais como conveniência, diversão, oportunidade, conforto ou saúde) que representam essencialmente interesses intangíveis do seu primeiro comprador. (James Brian Quinn, Jordan J. Baruche Penny Cushman Paquette, Scientific American, vol. 257, n. 2, December 1987, p. 50 apud Fitzsimmons e Fitzsimmons (2005)

Fitzsimmons e Fitzsimmons (2005) relata ainda, após reflexões, o conceito trazido por Earl Sasser, Paul Olsen, e Daryl Wyckoff:

\begin{abstract}
Uma definição precisa de bens e serviços deve distingui-los com base em seus atributos. Um bem é um objeto físico tangível ou produto que pode ser criado e transferido; ele tem uma existência através do tempo e, desse modo, pode ser criado e usado posteriormente. Um serviço é intangível e perecível; é uma ocorrência ou processo que é criado e usado simultaneamente ou quase simultaneamente. Embora o consumidor não possa conservar o serviço real após ele ter sido produzido, o efeito do serviço pode ser mantido. (Earl Sasser, R. Paul Olsen e D. Daryl Wyckoff, Management of Service Operations, Allyn e Bacon, Boston, 1978, p.8. apud Fitzsimmons e Fitzsimmons (2005))
\end{abstract}

Finalmente Fitzsimmons e Fitzsimmons (2005) apresentam a sua formulação dizendo que um serviço é uma experiência perecível, intangível, desenvolvida para um consumidor que desempenha o papel de co-produtor.

Carvalho e Paladini (2005) consideram que dentre as várias definições de serviços disponíveis na literatura a que mais se aproxima da materialidade é a da NBR ISO9004-2: “Serviço: resultado gerado por atividades na 'interface entre fornecedor e cliente' e por atividades internas do fornecedor para atender às necessidades do cliente" (CARVALHO e PALADINI, 2005, p. 332).

Peter Hill e Philippe Zarifian (apud CARVALHO e PALADINI, 2005) descrevem uma situação social de serviço, ou uma relação de serviço em torno de uma operação de “mudança de condição”:

Um serviço pode ser definido como uma 'mudança' na condição de uma pessoa ou de um bem pertencente a um agente econômico, que vem à baila como resultado da atividade de outro agente econômico, por acordo prévio, ou seja, solicitação da pessoa ou agente econômico anterior. (p. 332)

Serviço é uma organização e uma mobilização, a mais eficiente possível, de recursos para interpretar, compreender e gerar a 'mudança' nas condições de atividades do destinatário do serviço. (p.332)

Com base nessas definições é possível considerar que:

- As atividades do cliente na interface com o fornecedor podem ser essenciais à prestação do serviço. 
- A entrega ou uso de produtos tangíveis pode fazer parte da prestação do serviço.

- Um serviço pode estar vinculado à produção e ao fornecimento de um produto tangível.

\subsubsection{Características dos serviços}

A definição do serviço, então, requer que sejam arroladas algumas características.

A primeira característica seria a intangibilidade, ou seja, o fato de que a maior parte dos benefícios oferecidos por um serviços não estar associada a um bem.

A segunda característica elencada por Carvalho e Paladini (2005) é a heterogeneidade, pois os serviços são caracterizados pela realização de tarefas com base no relacionamento entre as pessoas. Assim, este componente se torna responsável pela imprevisibilidade e pela heterogeneidade que permeiam as ações, reações, expectativas e as situações pessoais nos serviços. A variabilidade do cliente, ou usuário, implica na variabilidade do atendimento.

A terceira característica diz respeito à não estocabilidade do serviço. O serviço só é realizado e entregue no mesmo momento, por isso não é possível usar o conceito de estoque em serviços.

Uma quarta característica é a necessidade de participação do cliente nos serviços, pois estes precisam da presença do cliente para a sua produção. Operações que produzem bens materiais têm baixo nível de contato com o cliente final. Já no caso do serviço, existe um alto nível de contato entre o consumidor e a operação. (CARVALHO e PALADINI, 2005)

A simultaneidade dos serviços é a quinta característica, pois os serviços são freqüentemente produzidos simultaneamente com seu consumo ao contrário dos bens que quase sempre são produzidos antes de o consumidor recebê-los.

A sexta e última importante característica dos serviços é a qualidade. Em razão de os consumidores não participarem do processo de produção dos bens, os julgamentos sobre a qualidade da operação são inferidos com base na qualidade dos próprios bens. Entretanto, nos serviços, o consumidor, que provavelmente participa da operação, não julga apenas seu resultado, mas também os aspectos de sua produção. Em outras palavras, a qualidade em serviços é sempre relativa e depende da percepção do usuário (GRONROSS, 1993). 


\subsubsection{Tipos de serviços}

Las Casas (2004) propõe que há dois diferentes tipos de serviços a serem comercializados.

O primeiro tipo categorizado pelo autor é constituído por aqueles serviços em que o produto do serviço é intangível. Las Casas exemplifica que um consultor de empresas quando comercializa seus serviços, tem como enfoque seu conhecimento. Ele pode usar componentes materiais de comercialização como relatórios, propostas, ou outro qualquer. No entanto, o que ele comercializa realmente é seu conhecimento. É como um advogado, um professor ou algum outro profissional liberal. $\mathrm{O}$ autor afirma que o objeto de comercialização principal destes profissionais é intangível.

O segundo tipo apresentado é o dos serviços que são consumidos junto com os bens, ou seja, o objeto de comercialização inclui produtos tangíveis e intangíveis. É o caso dos restaurantes. Nesse caso o cliente ficará exposto a uma combinação de prestação de serviços de atendimento (intangível) e de refeições (tangível). Sendo assim, não adianta apenas servir boa comida ou apenas dar bom atendimento. Os dois devem ser considerados sempre nestas interações.

Carvalho e Paladini (2005) classificam os tipos de serviços pelo volume e pela variedade em três grandes categorias: serviços profissionais, lojas de serviços e serviços de massa.

Para os autores, os serviços de massa são aqueles que compreendem transações com muitos clientes (alto volume), envolvendo tempo de contato limitado e alta padronização na prestação do serviço (baixa variedade). Esses serviços em geral são predominantemente baseados em equipamento e orientados para o produto, com a maior parte do valor adicionado sendo adicionado no escritório de retaguarda (back office), com relativamente pouca atividade de julgamento exercida pelo pessoal da linha de frente (front office) e pelo usuário. O pessoal empregado não apresenta alto nível de qualificação, com tarefas e procedimentos prescritos. Alguns exemplos desse tipo: serviços de transporte público, cursos à distância fornecidos a milhares de pessoas e internet banking.

Os serviços profissionais são definidos como organizações de alto contato com os clientes, despendendo um tempo considerável no processo de prestação do serviço. Portanto, são serviços que atendem a um número limitado de clientes (volume baixo) e de forma personalizada. Esses serviços proporcionam altos níveis de customização (variedade alta), sendo o processo do serviço altamente adaptável para atender às necessidades individuais dos clientes. Neste tipo de serviço, grande parte do trabalho pode ocorrer nas instalações do 
cliente. Como exemplo Carvalho e Paladini (2005) citam empresas de consultoria, projetos de engenharia especiais, serviços médicos especializados, departamento de bancos que gerenciam contas de alto valor.

Já as lojas de serviços são caracterizadas por níveis intermediários de contato com o cliente, ou seja, estão no meio-termo entre a padronização e a customização. Os volumes de clientes atendidos e as combinações de valor das atividades da linha de frente e da retaguarda são intermediários entre os do serviço profissional e os de serviços de massa. São exemplos deste tipo de serviços bancos, lojas de varejo, restaurantes, hospitais.

\subsubsection{Serviços públicos}

Dentre as diferentes formas de definir os serviços e de classificá-los percebe-se a ausência de um cuidado especial com o serviço público. O conceito de serviço público não é estático. O conceito altera-se segundo as necessidades do tempo e do interesse público, dispondo de diversas significações conforme a época e a localidade escolhida para análise. Assim, em toda história as diversidades culturais, temporais, espaciais, tecnológicas, econômicas, têm influenciado a definição do que seja serviço público. (CUNHA, 2008)

Cunha (2008) coloca que é importante entender, antes de conceituar, que serviço público difere da função pública. A função pública é a atividade endereçada aos fins essenciais do Estado, enquanto o serviço público representa a atividade do Estado visando aos objetivos de bem-estar social e à satisfação das necessidades individuais do cidadão.

Maciel (2002) afirma que o serviço público tem como objetivo único a satisfação coletiva, ou seja, todos os serviços devem ser prestados em função da coletividade, do usuário final que é o cidadão.

Muitos autores, de diversas áreas do conhecimento conceituam serviço público. O jurista Celso Antônio Bandeira de Melo (1999) conceitua:

Serviço público é toda a atividade de oferecimento de utilidade ou comodidade material fruível diretamente pelos administrados, prestados pelo Estado ou por quem lhe faça às vezes, sob um regime de Direito Público - portanto, consagrador de prerrogativas de supremacia e de restrições especiais - instituído pelo Estado em favor de interesses que houver definido como próprios no sistema normativo. (...) a noção de serviço público há de se compor necessariamente de dois elementos: um deles, que é seu substrato material, consiste na prestação de utilidade ou comodidade fruível diretamente pelos administrados; o outro, traço formal indispensável, que lhe dá justamente caráter de noção, consistente em um específico regime de Direito Público, isto é, numa "unidade normativa (MELO, 1999, p.27). 
Já Hely Lopes Meirelles (1999), na obra Direito Administrativo Brasileiro define serviço público como:

Serviço Público é todo aquele prestado pela Administração ou por seus delegados, sob normas e controles estatais, para satisfazer necessidades essenciais ou secundárias da coletividade ou simples conveniências do Estado. Fora dessa generalidade não se pode indicar as atividades que constituem serviço público, porque variam de acordo com a exigência de cada povo e de cada época. Nem se pode dizer que são as atividades coletivas vitais que caracterizam os serviços públicos, porque ao lado destas existem outras, sabidamente dispensáveis pela comunidade, que são realizadas pelo Estado como serviço público (MEIRELLES, 1999, p.29).

Maria Silvya Zanella Di Pietro (1999) defende que serviço público é toda atividade material que a lei atribui ao Estado para que exerça diretamente ou por meio de seus delegados, com o objetivo de satisfazer concretamente as atividades coletivas, sob regime jurídico total ou parcialmente público.

Já Moreira Neto (2000) traz a visão tradicional e a visão contemporânea do conceito de serviço público:

Conceito "tradicional" de serviço público: "atividade da Administração Pública que tem por fim assegurar de modo permanente, contínuo e geral, a satisfação de necessidades essenciais ou secundárias da sociedade, assim por lei consideradas, e sob as condições impostas unilateralmente pela própria Administração". Conceito "contemporâneo" de serviço público: "as atividades pelas quais o Estado, direta ou indiretamente, promove ou assegura a satisfação de interesses públicos, assim por lei considerados, sob regime jurídico próprio a elas aplicável, ainda que não necessariamente de direito público. (MOREIRA NETO, 2000, p. 99)

A doutrina do Direito faz uma classificação tradicional de serviços públicos, dividindo-os em próprios e impróprios (ou virtuais e objetivos): os próprios são aqueles que devem ser prestados diretamente pelo Estado sem possibilidade de delegação ou concorrência; os impróprios são aqueles que podem ser prestados pelos particulares e também indiretamente pelo Estados, mediante suas autarquias, empresas públicas ou sociedades de economia mista (CUNHA, 2008).

Outra classificação diz respeito ao fornecedor do serviço. Denominado critério orgânico ou subjetivo, no qual se define ou caracteriza o serviço público em atenção ao ente ou a pessoa que o satisfaz ou realiza. Chegando a se falar que, segundo este critério o serviço público seria concebido como um organismo público, ou seja, um complexo de agentes que uma pessoa pública afeta a uma tarefa (MEIRELLES, 1999).

Di Pietro (1999) afirma que o critério material ou funcional vem a definir o serviço público como a atividade que tem por objeto a satisfação de necessidade ou interesses 
coletivos, ou seja, leva-se em conta não o sujeito que presta o serviço, mas o fator primordial para esta definição vem a ser o que a população deseja, o que esta elege como dever do poder público fornecer, variando de acordo com cada autor qual o requisito, designação ou nomeclatura dessa necessidade, podendo ser chamada de caráter "geral”, “coletivo”, “público”, ou de "utilidade”. Alguns ainda fazem menção simultânea aos três adjetivos da necessidade: interesse “coletivo”, “geral” e “público”.

Todavia, seguindo o tema do serviço público, Cunha (2008) afirma que independente da classificação, tem-se que um dos princípios que o tangem é a eficiência, isto é, a obrigação da Administração Pública em prestar seus serviços de forma rápida, perfeita e com rendimento. Por isso exige-se a constante atualização e melhoramento do serviço, ou seja, sua constante mutabilidade.

\subsection{Qualidade no serviço público brasileiro}

A busca pela qualidade no serviço público, principalmente no Brasil, deu-se principalmente com a reforma gerencial iniciada em 1995 - não que antes dessa data nada se fazia pela qualidade dos serviços, contudo esse ano é o marco da institucionalização desse trabalho que hoje está voltado completamente para atender as necessidades dos cidadãos.

Assim, para melhor entender o conceito de qualidade no serviço público brasileiro é preciso antes fazer uma breve análise da evolução da administração pública brasileira, dentro do modelo gerencial para compreender de forma plena a busca pela qualidade que é travada hoje no serviço público brasileiro, conforme os capítulos que se seguem.

\subsubsection{Evolução da administração pública brasileira}

A reforma administrativa no Brasil se tornou um tema central em 1995, após a eleição e posse de Fernando Henrique Cardoso. Bresser-Pereira (1998) considera que nesse momento estava claro para a sociedade brasileira que essa reforma tornara-se condição, de um lado, da consolidação do ajuste fiscal do Estado brasileiro, e, de outro, da existência no país de um serviço público moderno, profissional e eficiente, voltado para o atendimento das necessidades dos cidadãos.

Todavia essa reforma não foi a primeira tentativa de organizar e estruturar o aparelho estatal brasileiro.

Tendo em vista as práticas patrimonialistas (usar a máquina administrativa com fins privados, escusos) correntes na cultura brasileira, o Presidente Getúlio Vargas optou pela adoção de um modelo que pautasse pelo controle minucioso das atividades-meio do estado. 
Ou seja, para “colocar ordem na casa”, buscou referências no modelo idealizado por Max Weber, acreditando que a burocracia, dado seu caráter rígido e hierarquizado poderia ordenar a máquina administrativa no Brasil. Chiavenato (2006) afirma que está aí o primeiro modelo estruturado de administração do país.

Nessa época, em virtude da desconfiança total que havia no servidor público, o modelo burocrático revelava-se ser o mais adaptado. Com isso, Vargas almejava basicamente três medidas: criar uma estrutura administrativa organizada, uniforme; estabelecer uma política de pessoal com base no mérito; e acabar com o nepotismo e corrupção existentes. (CHIAVENATO, 2006). Este último objetivo colaborava, obviamente, com sua estratégia de retirar dos cargos públicos os indicados pelas oligarquias regionais que se opunham a ele e que, via de regra, haviam sustentado a República Velha (FAUSTO, 2006; FAORO, 2001).

Com o passar do tempo, percebeu-se que a burocracia, se exacerbada em suas características, pode levar a disfunções e revela-se um modelo pouco flexível, inadequado em cenários dinâmicos, os quais exigem agilidade (BRESSER-PEREIRA, 1998). Segundo Bresser-Pereira (1998) que a partir daí é possível identificar diversas tentativas de desburocratizar a máquina pública: a criação do COSB (Comitê de Simplificação da Burocracia); da SEMOR (Secretaria de Modernização da Reforma Administrativa); o Decreto-Lei $n^{\circ}$ 200, de 1967; o PND (Programa Nacional de Desburocratização); e ainda outros de menor vulto que não tiveram o sucesso desejado. Até que em 1995, com a edição do Plano Diretor de Reforma do Estado, começa a implantação, no Brasil, do chamado modelo gerencial.

\subsubsection{1 - O modelo gerencial no Brasil}

O modelo gerencial, em sua fase inicial, implica em administrar a res publica de forma semelhante ao setor privado, de forma eficiente, com a utilização de ferramentas que consigam maximizar a riqueza do acionista, ou a satisfação do usuário (considerando-se a realidade do serviço público) (PAULA, 2007). Nesse sentido buscar-se-ia a adoção de uma postura mais empresarial, empreendedora, aberta a novas idéias e voltada para o incremento na geração de receitas e no maior controle dos gastos públicos (PAULA, 2007).

Chiavenato (2006) mostra que esse modelo é mais bem entendido considerando o cenário em que foi concebido. No plano econômico, dada a crise do petróleo na década de 1970, esgotaram-se as condições que viabilizavam a manutenção do Walfare State (Estado do Bemestar Social), onde prevalecia o entendimento de que cabia ao Estado proporcionar uma ampla gama de serviços à população, respondendo esse por saúde, educação, habitação, etc. A partir 
daí começa a ser difundida a idéia de devolução ao setor privado daqueles serviços que o Poder Público não tem condições de prestar com eficiência (privatizações), devendo o Estado desenvolver aquilo que cabe intrinsecamente a ele fazer (diplomacia, segurança, fiscalização, etc.). O ideal de um Estado mínimo volta a ganhar força.

Bresser-Pereira (1998) afirma que, no âmbito da reforma gerencial, o que se propôs, na verdade, não foi o Estado mínimo, mas a quebra de um paradigma com a redefinição do que caberia efetivamente ao Estado fazer e o que deveria ser delegado ao setor privado. Como referência, é possível citar a obra de Osborne e Gaebler (apud CHIAVENATO, 2006), Reinventando o Governo, onde são destacados princípios incorporados na construção do modelo gerencial brasileiro, tais como:

- formação parcerias;

- foco em resultados;

- visão estratégica;

- Estado catalisador, ao invés de remador;

- visão compartilhada; e

- busca da excelência.

Abrúcio (1997) sustenta que o modelo gerencial (puro, inicial), buscou responder com maior agilidade e eficiência os anseios da sociedade, insatisfeita com os serviços recebidos do setor público. Afirma também que o modelo representou o início do Managerialism, que, atualmente, congrega ainda duas correntes: o Consumerism e o Public Service Orientation (PSO). O autor diz que se tivermos em mente uma linha de continuidade, é possível inferir que a administração gerencial evoluiu do Managerialism para o PSO, sem, contudo ser possível afirmar que o PSO representa a versão final da administração gerencial.

A preocupação primeira do modelo gerencial foi o incremento da eficiência, tendo em vista as disfunções do modelo burocrático. Nessa fase o usuário público é visto tão somente como o financiador do sistema. No Consumerism há o incremento na busca pela qualidade, decorrente da mudança do modo de ver o usuário do serviço, de mero contribuinte para cliente consumidor de serviços públicos. Nesse momento há uma alteração no foco da organização, a burocracia, que normalmente é auto-referenciada - ou seja, voltada para si mesma - passa a observar com maior cuidado a razão de sua existência: a satisfação de seu consumidor. Com isso buscar-se conhecê-lo por meio, dentre outras coisas, de pesquisas de opinião e procura-se proporcionar um atendimento diferenciado com vistas a contemplar necessidades individualizadas. (CHIAVENATO, 2006) 
Na fase mais recente, o entendimento de que o usuário do serviço deve ser visto como cliente-consumidor perdeu força, principalmente porque a idéia de consumidor poderia levar a um atendimento melhor para alguns e pior para outros, num universo em que todos têm os mesmos direitos. É possível perceber isso quando levamos em consideração que os clientes melhores organizados e estruturados teriam mais poder para pleitear mais ou melhores serviços, culminando em prejuízo para os menos estruturados. Por isso, nesta abordagem é preferível o uso do conceito de cidadão, que ao invés de buscar a sua satisfação, estaria voltado para a consecução do bem-comum. Com isso o que se busca é a equidade, ou seja, o tratamento igual a todos os que se encontram em situações equivalentes. (ABRÚCIO, 1997)

Nesse diapasão, os cidadãos teriam, além de direitos, obrigações perante a sociedade, tais como a fiscalização da res publica, vindo a cobrar, inclusive, que os mais gestores seja responsabilizados (accountability) por atos praticados com inobservância da legislação ou do interesse público.

\subsubsection{A administração pública voltada para o cidadão}

O modelo de administração gerencial inspirou-se na administração privada, mas procurou manter uma distinção fundamental assentada na defesa do interesse público. Dentro do modelo gerencial, a melhoria da qualidade dos serviços prestados ao cidadão assumiria papel muito importante. Trata-se de abandonar o caráter auto-referente da administração burocrática, voltada exclusivamente aos interesses do aparelho do Estado, para colocar em prática as novas idéias gerenciais, oferecendo à sociedade um serviço público de melhor qualidade, em que todas as atenções são centradas nos cidadãos. Vale notar que o caráter mais democrático da nova gestão pública adviria da sua orientação ao público, além da participação dos cidadãos e controle social da gestão (COUTINHO, 2000).

A profunda transformação nas relações entre a administração pública e seus usuários deve-se, em grande medida, à crise do atendimento ao cidadão. Usuários de serviços públicos se mostravam insatisfeitos, de forma recorrente, com a qualidade do atendimento. Além disso, os cidadãos exigem, cada vez mais, a prestação de serviços de qualidade que consigam dar resposta às suas demandas crescentes (PLEGUEZUELOS apud COUTINHO, 2000). Por esses motivos, a prestação dos serviços tornou-se um fator bastante crítico para a administração pública no Brasil e no mundo.

As razões para a insatisfação com os serviços prestados passam, entre outros problemas, pela ineficiência e ineficácia do atendimento. Por sua vez a falta de conhecimento 
e a resistência à adoção dos instrumentos necessários para a melhoria do atendimento dificultam qualquer mudança significativa nessa área (COUTINHO, 2000).

O autor ainda afirma que a administração pública tenta hoje solucionar esses problemas trazendo o cidadão para o centro das suas atenções e preocupações. O conjunto de mudanças no setor público, implementadas atualmente por muitos países, tendo em vista as expectativas crescentes da sociedade, concentra-se, então, na figura do usuário. Com isso, uma parte importante dos problemas trazidos à administração pública passa a ser resolvida com mais facilidade, olhando mais atentamente para fora das organizações e, conseqüentemente, para aqueles que usufruem seus serviços. Além disso, a administração pública voltada para o cidadão é auxiliada hoje pelas transformações tecnológicas que possibilitam o uso de uma série de instrumentos novos para o atendimento. Os avanços na informática, redes e softwares, e nas telecomunicações trazem grandes benefícios para essa mudança no modelo administrativo.

\subsubsection{Foco no cidadão: princípios e desenvolvimento conceitual}

A administração pública voltada para o cidadão-usuário tem origem ainda nos anos de 1980. Em 1987, a OCDE publica documento, intitulado Administration as Service, the public as client, que traz alguns princípios gerais dessa nova administração. (COUTINHO, 2000). Segundo esse documento, os clientes devem saber como a administração funciona, o que a constrange, como é controlada e quem são os responsáveis. Além disso, a administração deve possibilitar a participação dos clientes, satisfazer suas necessidades e ser, ao máximo, acessível ao público.

Contudo é somente durante a década de 1990 que a administração com foco no cidadão experimenta uma desenvolvimento expressivo, difundindo-se para países como o Brasil e os Estados Unidos. Em setembro de 1993, o presidente dos Estados Unidos, por meio de uma Ordem Executiva, estabeleceu as bases para a adoção, pelo governo federal, de uma administração centrada no cliente, instituindo que as agências adotassem uma série de medidas, como, por exemplo, a possibilidade de escolha aos clientes, em termos de fontes de serviço, e a promoção de meios de endereçar suas reclamações (COUTINHO, 2000). Essa nova política é reforçada por documentos publicados posteriormente, inseridos no programa National Performance Review, em que o cliente é colocado em primeiro lugar. O National Performance Review falava em reinventar o Estado. Sua idéia central não era diminuir o Estado a qualquer preço, mas torná-lo mais eficiente e orientado para o cidadão-cliente (CLINTON; GORE apud COUTINHO, 2000). 
As reformas em curso pelo governo americano, bem como em outros países da OCDE, com o enfoque voltado para os clientes, inspirou-se bastante na perspectiva empresarial. Uma das principais razões alegadas para tratar as pessoas com a mesma atenção que as empresas privadas dispensam à sua clientela se deve, exatamente, ao sucesso que algumas dessas empresas obtiveram implantando programas que valorizavam as necessidades dos clientes. Nesse sentido, o foco no cidadão na administração pública, assim como todo o modelo gerencial, teve inicialmente grande influência de uma mentalidade de mercado, passando a adotar técnicas e métodos da administração de empresas. Coutinho (2000) afirma que essa abordagem tem tido um impacto tão grande nas organizações públicas, que o primeiro passo geralmente tem sido identificar quem é o cliente, compreendendo as pessoas que usufruem dos serviços públicos.

Para muitos autores, é fundamental para a reforma gerencial que os cidadãos sejam vistos como clientes (costumers). Nesse sentido, a importação do termo cliente da administração de empresas constituiria um avanço também para a cidadania. "Ver o cidadão como um cliente significa apenas dar-lhe a devida atenção, dedicar-lhe o respeito que ele não tem nas práticas da administração pública burocrática, auto-referida, voltada para seu próprio poder” (BRESSER-PEREIRA, 1998). Assim, a orientação para o cliente significaria atender às suas necessidades e respeitá-lo, sem usurpar seu direito de participar nas tomadas de decisão de políticas públicas.

\footnotetext{
Dentro dessa perspectiva, as organizações públicas mudam de comportamento quando se voltam para os seus clientes. Elas se tornam mais eficientes e preocupadas com a qualidade dos serviços que prestam ao público, a ponto de não somente satisfazer as expectativas dos clientes como também de superá-las por meio da competição. A criação de um ambiente altamente competitivo entre as organizações públicas nos moldes do mercado, suscita a valorização máxima do cliente. (COUTINHO, 2000, p. 21)
}

Todavia, nos últimos anos, é cada vez mais utilizado o conceito de administração com foco no cidadão, ao invés do cliente. Isso ocorre pela percepção crescente de que, no setor público, o critério de eficiência está subordinado ao critério democrático. Assim, ao mesmo tempo em que é preciso constituir uma administração pública eficiente, é necessário preservar prioritariamente os valores democráticos. Da mesma forma, a importação de práticas e conceitos organizacionais do setor privado não deve suplantar o objetivo maior do Estado que é o interesse público.

Bresser-Pereira (1998) afirma então que a especificidade original do setor público está no caráter eminentemente político. Dessa forma, enquanto o setor privado é regido pelo 
mercado e o lucro, a administração pública não pode ser compreendida fora dos princípios de poder e legitimidade. Isso faz com que a cidadania assuma uma importância infinitamente maior no setor público, onde o cidadão-cliente é um cidadão-cidadão, um cidadão pleno, que é o objeto dos serviços públicos e também seu sujeito, na medida em que se torna partícipe na formação das políticas públicas e na avaliação dos resultados.

Osborne e Plastrik (apud COUTINHO, 2000) colocam que é necessário deixar claro quatro conceitos para que seja possível trabalhar com o viés do cidadão-cliente:

- Clientes primários: indivíduo ou grupo cujo trabalho da administração pública é primordialmente desenhado para ajudar.

- Clientes secundários: outros indivíduos ou grupo cujo trabalho de administração pública é desenhado para beneficiar, mas menos diretamente do que os clientes primários.

- Compliers: aqueles que devem se submeter a leis e regulamentações, por exemplo, o contribuinte em relação à Receita Federal.

- Stakeholders: indivíduos ou grupos que têm interesse no desempenho do sistema ou organização pública, por exemplo, os professores nas escolas públicas.

Como já citado, a administração pública voltada para o cidadão pode ser definida como um modelo gerencial cujo objetivo é oferecer serviços públicos de maior qualidade, atendendo melhor às demandas dos seus usuários. Entretanto é importante dizer que os cidadãos podem ser ou não usuários de serviços públicos específicos, mas são parte de toda uma comunidade e, portanto, contribuem e recebem benefícios da administração pública. Os cidadãos são também portadores de direitos e deveres e, ao contrário dos clientes do setor privado, freqüentemente não podem escolher um serviço alternativo, caso estejam insatisfeitos com o serviço prestado pelo setor público. Assim, funcionários públicos não atendem somente aos usuários diretos, mas preservam os direitos de todos os cidadãos. Isso significa que eles equilibram os objetivos potencialmente conflituosos de satisfação dos usuários com a proteção dos interesses de toda a comunidade ou cidadãos de um país. Essa é a principal razão pela qual fornecer um serviço de alta qualidade no setor público é muito mais difícil do que no mercado. 


\subsubsection{Qualidade como satisfação do cidadão-usuário}

O conceito de qualidade varia bastante ao longo da história da teoria administrativa. Do controle clássico de qualidade, como forma de detectar desajustes em especificações técnicas de um produto, passou-se a definir qualidade como o conjunto de características de um produto ou serviço que satisfazem as necessidades expectativas do cliente. Segundo Coutinho (2000) qualidade pode ser minimamente definida como a maximização do sucesso do cliente. $\mathrm{O}$ autor ainda sintetiza as bases das estratégias de uma organização voltada ao atendimento do cliente em três grandes categorias: qualidade como maximização do sucesso do cliente; atendimento ao cliente como diferencial competitivo; e tecnologia da informação gerando soluções.

A Administração de Qualidade Total (Total Quality Management - TQM), inverte todos os conceitos tradicionais de administração. Nela, os clientes passam a ser as pessoas mais importantes para a organização. Só depois vêm os interesses dos que servem ao cliente e os da própria administração (OSBORNE; GAELBLER apud COUTINHO, 2000). Além disso, a Administração de Qualidade Total enfatiza a constante mensuração e melhoria nos serviços prestados.

Esta idéia de qualidade tem sido incorporada à esfera pública, na qual o cidadão pode ser considerado como usuário, na medida em que é receptor da ação das organizações públicas. Nesse caminho é possível conceituar a qualidade no serviço público como a satisfação das necessidades e expectativas dos cidadãos, supondo ainda a redução dos custos e a melhora permanente dos processos de acordo com as exigências da sociedade.

É possível então esquematizar os fundamentos da administração pública voltada para o cidadão:

Recursos e ações inovadoras gerando soluções
Qualidade como satisfação do cidadãousuário

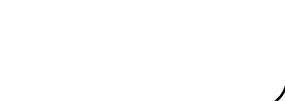

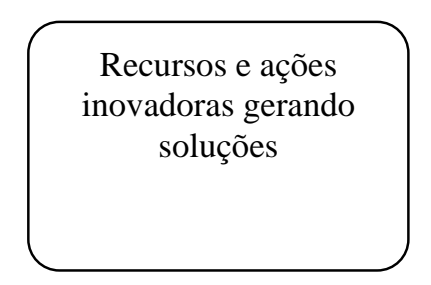

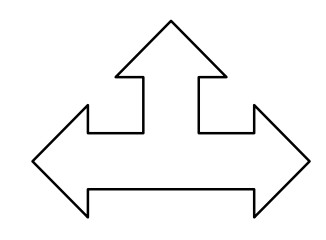

Atendimento ao cidadão como diferencial de qualidade

Figura 1 - Fundamentos da Administração Pública voltada ao cidadão. 
Qualidade supõe, portanto, maior eficácia e eficiência. Isto é, supõe que os serviços prestados ao público tenham um impacto real nas suas necessidades e expectativas, enquanto melhora a relação ente os recursos empregados e os resultados obtidos. As implicações do conceito de qualidade total para a administração pública são muitas. Uma das principais conseqüências é a ampliação do conceito de cliente, considerando o cidadão como um cliente que recebe serviços, ao mesmo tempo em que se concebe a organização como um sistema integrado de provedores e clientes internos.

Coutinho (2000) defende que os fundamentos da nova administração pública voltada para o cidadão mostram é que, se a qualidade dos serviços de uma organização depende da satisfação do usuário, então, o seu atendimento deve ser sempre o melhor possível, fazendo com que haja um diferencial qualitativo substancial. Para isso, é preciso adotar ações inovadoras capazes de mobilizar todos os recursos disponíveis em busca de soluções eficientes e eficazes, dentro do processo de trabalho das organizações públicas.

Porém, como medir a qualidade dos serviços prestados ao cidadão? Evidentemente a resposta está na satisfação dos usuários. Cidadãos-usuários satisfeitos é sinal de boa qualidade nos serviços prestados pelas organizações. Quanto maior a satisfação do usuário melhor é a qualidade do atendimento e cumprimento das expectativas do público. Vale ressaltar que, a rigor, os padrões de bons serviços aos cidadãos devem ser obtidos com os próprios usuários, verificando o que desejam. Portanto, passa a ser crucial a realização de pesquisas junto aos cidadãos-usuários, para se obter informações a respeito de suas necessidades, bem como sobre formas de melhorar o atendimento. Muitos países já realizam pesquisas rotineiras junto aos usuários de serviços públicos. No Brasil, essa iniciativa é bastante recente.

\subsection{Instrumento de mensuração da qualidade em serviços}

Para uma boa prestação de serviço é necessário saber como vai o desempenho do trabalho desenvolvido, de forma que se possa melhorar e incrementar os serviços prestados.

Diante dessas necessidades latentes surgiram algum instrumentos (ou ferramentas) para fazer a avaliação de desempenho dos serviços prestados, com o objetivo de suprir as lacunas existentes e assim fazer um efetivo gerenciamento da qualidade.

Nesse trabalho estuda-se o instrumento SERVQUAL e seu modelo de gaps de qualidade e a sua adaptação para o serviço público brasileiro. 


\subsubsection{O instrumento SERVQUAL e o modelo "gap"}

Parasuraman, Zeithaml e Berry (1988) propuseram, em um trabalho pioneiro, uma medição de qualidade do serviço, baseada no modelo de satisfação de Oliver (apud ABACKERLI et al, 2005), afirmando que a satisfação do cliente é função da diferença entre a expectativa e o desempenho. Dessa forma, a avaliação da qualidade de um serviço, por um cliente, é feita por meio da diferença entre a sua expectativa e o seu julgamento do serviço, em certas dimensões da qualidade em serviços.

O gap, ou diferença entre a expectativa e o desempenho, é uma medida da qualidade do serviço em relação a uma característica específica. Os critérios chamados por Parasuraman et al, 1988 (apud ABACKERLI et al, 2005) de dimensões da qualidade, são características genéricas do serviço subdivididas em itens, que delineiam serviço sob o ponto de vista do cliente que irá julgá-lo.

O modelo gap é ilustrado na Figura 1, que mostra a forma pela qual o cliente avalia a qualidade do serviço e como a empresa pode avaliar analiticamente a qualidade de um serviço prestado. O modelo, descrito a seguir, demonstra as influências das várias discrepâncias ocorridas na qualidade dos serviços, e pode ser dividida em dois segmentos distintos: o contexto gerencial e o contexto do cliente.

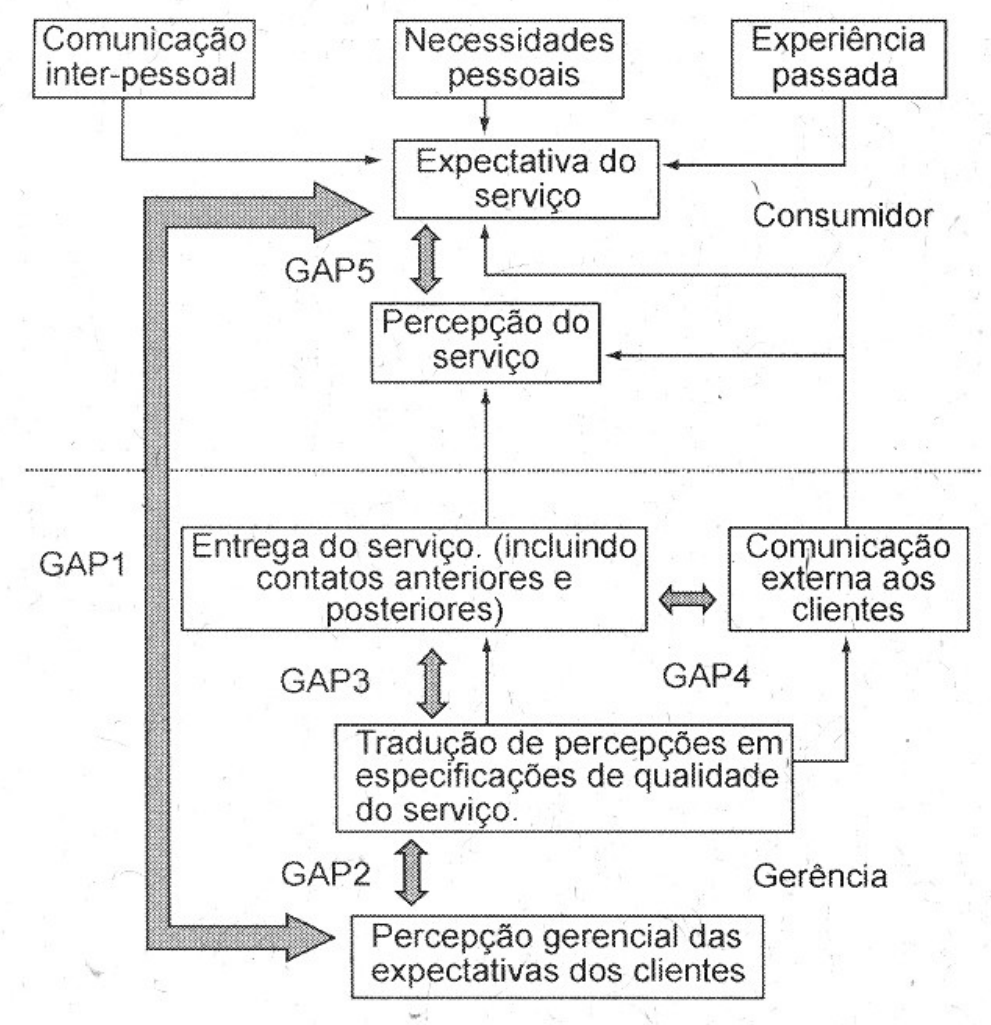

Figura 1. Modelo “GAP” de Qualidade dos Serviços

Fonte: Parasuraman et al (apud ABACKERLI et al, 2005) 
Em relação à Figura 1, primeiramente tem-se o gap 1, ou a discrepância entre a expectativa do cliente e a percepção gerencial sobre esta expectativa. O gap 2 compreende a discrepância entre a percepção gerencial das expectativas dos clientes e a transformação destas em especificações de qualidade dos serviços. Por sua vez, as empresas de serviço são altamente dependentes do contato interpessoal entre o fornecimento de serviços, é o gap 3 que corresponde à discrepância entre os padrões e especificações da empresa e o que realmente é fornecido ao cliente. O gap 4 é a discrepância entre a promessa realizada pelos meios de comunicação externa e o que realmente é fornecido.

Do modelo fica claro que o julgamento sobre a qualidade dos serviços depende de como os clientes percebem o real desempenho do serviço, a partir de suas próprias expectativas. Assim, o gap 5 consiste na discrepância entre a expectativa do cliente e a sua percepção do serviço, como expresso pela equação (ABACKERLI et al, 2005):

$$
\text { gap } 5 \text { = f(gap 1, gap 2, gap 3, gap 4) }
$$

Como mostra a equação, a percepção de qualidade dos serviços, do ponto de vista do cliente, chamada gap 5, depende da direção e magnitude das seguintes discrepâncias: gap 1, gap 2, gap 3, gap 4, acima conceituadas e associadas com o projeto, marketing e prestação de serviços na organização.

Outra conclusão importante destes autores (PARASURAMAN et al apud ABACKERLI et al, 2005) foi obtida por meio de um grupo focal. Constatou-se que os clientes utilizam os mesmos critérios para chegar a um julgamento avaliativo sobre a qualidade do serviço prestado, independentemente do tipo de serviço considerado. Estes critérios puderam ser generalizados em 10 categorias denominadas de dimensões da qualidade. Essas dimensões representam os fatores críticos da prestação de um serviço, que podem causar a discrepância entre expectativa e desempenho.

Parasuraman et al (apud ABACKERLI et al, 2005), tomando como base as dez dimensões da qualidade dos serviços, desenvolveram um questionário chamado de escala SERVQUAL, utilizando as diversas ocorrências de satisfação por meio do modelo gap. Este questionário está representado na tabela 1, sendo conhecido como instrumento SERVQUAL. 


\begin{tabular}{|c|c|c|c|}
\hline Item & & Expectativa (E) & Desempenho (D) \\
\hline 1 & Aspectos & Eles deveriam ter equipamentos modernos. & XYZ têm equipamentos modernos. \\
\hline 2 & Tangíveis & $\begin{array}{l}\text { As suas instalações físicas deveriam ser visualmente } \\
\text { atrativas. }\end{array}$ & $\begin{array}{l}\text { As instalações físicas de XYZ são visualmente atra- } \\
\text { tivas. }\end{array}$ \\
\hline 3 & . & $\begin{array}{l}\text { Os seus empregados deveriam estar bem vestidos e } \\
\text { asseados. }\end{array}$ & Os empregados de XYZ'são bem vestidos e asseados. \\
\hline 4 & & $\begin{array}{l}\text { As aparênciąs das instalações das empresas deveriam } \\
\text { estar conservadas de acordo com o serviço oferecido. }\end{array}$ & $\begin{array}{l}\text { A aparência das instalações físicas XYZ é conservada } \\
\text { de acordo com o serviço oferecido. }\end{array}$ \\
\hline 5 & Confiabilidade & $\begin{array}{l}\text { Quando estas empresas prometem fazer algo em certo } \\
\text { tempo, deveriam fazê-lo. }\end{array}$ & $\begin{array}{l}\text { Quando XYZ promete fazer algo em certo tempo, } \\
\text { realmente o faz. }\end{array}$ \\
\hline 6 & & $\begin{array}{l}\text { Quando os clientes têm algum problema com ęstas' } \\
\text { empresas elas, deveriam ser solidárias e deixá-los } \\
\text { seguros. }\end{array}$ & $\begin{array}{l}\text { Quando você tem algum problema com a empresa } \\
\mathrm{XYZ} \text {, ela é solidária e o deixa seguro. }\end{array}$ \\
\hline 7 & & Estas empresas deveriam ser de confiança. & XYZ é de confiança. \\
\hline 8 & & Eles deveriam fornecer o serviço no tempo prometido. & XYZ fornece o serviço no tempo prometido. \\
\hline 9 & & Eles deveriam manter seus règistros de forma correta. & XYZ mantém seus registros de forma correta. \\
\hline 10 & Presteza & $\begin{array}{l}\text { Não seria de se esperar que eles informassem os } \\
\text { clientes exatamente quando os serviços fossem execu- } \\
\text { tados. }\end{array}$ & $\begin{array}{l}\text { XYZ não informa exatamente quando os serviços } \\
\text { serão executados. }\end{array}$ \\
\hline 11 & & $\begin{array}{l}\text { Não é razoável esperar por uma disponibilidade ime- } \\
\text { diata dos empregados das empresas. }\end{array}$ & $\begin{array}{l}\text { Você não recebe serviço imediato dos empregados da } \\
\text { XYZ. }\end{array}$ \\
\hline 12 & . & $\begin{array}{l}\text { Os empregados das-empresas não têm que estar sem- } \\
\text { pre disponíveis em ajudar os clientes. }\end{array}$ & $\begin{array}{l}\text { Os empregados da XYZ não estão sempre dispostos a } \\
\text { ajudar os clientes. }\end{array}$ \\
\hline 13 & & $\begin{array}{l}\text { È normal que eles estejam muito ocupados em respon- } \\
\text { der prontamente aos pedidos. }\end{array}$ & $\begin{array}{l}\text { Empregados da XYZ estão sempre ocupados em } \\
\text { responder aos pediklos dos clientes. }\end{array}$ \\
\hline 14 & Segurança & $\begin{array}{l}\text { Clientes deveriam ser capazes de acreditar nos empre- } \\
\text { gados desta empresa. }\end{array}$ & Você pode acreditar nos empregados da XYZ. \\
\hline 15 & . & $\begin{array}{l}\text { Clientes deveriam ser capazes de sentirem-se seguros } \\
\text { na negociação com os empregados da empresa. }\end{array}$ & $\begin{array}{l}\text { Você se sente seguro em negociar com os empregados } \\
\text { da XYZ. }\end{array}$ \\
\hline 16 & & Seus empregados deveriam ser educados. & Empregados da XYZ são educados. \\
\hline 17 & & $\begin{array}{l}\text { Seus émpregados deveriam obter suporte adequado da } \\
\text { empresa para cumprir suas tarefas corretamente. }\end{array}$ & $\begin{array}{l}\text { Os empregados da XYZ não obtêm suporte adequado } \\
\text { da empresa para cumprir suas tarefas corretamente. }\end{array}$ \\
\hline 18 & Empatia & $\begin{array}{l}\text { Não/seria de se esperar que as empresas dessem aten } \\
\text { ção individual aos clientes. }\end{array}$ & XYZ não dão atenção individual a você. \\
\hline 19 & & $\begin{array}{l}\text { Não se pode esperar que os empregados dêem atenção } \\
\text { personalizada aos clientes. }\end{array}$ & Os empregados da XYZ não dão atenção pessoal. \\
\hline 20 & : & $\begin{array}{l}\text { É absurdo esperar que os empregados saibam quais são } \\
\text { as necessidades dos clientes. }\end{array}$ & $\begin{array}{l}\text { Os empregados da XYZ não sabem das suas necessi- } \\
\text { dades }\end{array}$ \\
\hline 21 & & $\begin{array}{l}\text { É absurdo esperar que estas emprésas tenham os me- } \\
\text { lhores interesses de seus clientes como objetivo. }\end{array}$ & $\begin{array}{l}\text { XYZ não têm os seus melhores interesses como } \\
\text { objetivo. }\end{array}$ \\
\hline 22 & $\therefore$ & $\begin{array}{l}\text { Não deveria se esperar que o horário de funcionamen- } \\
\text { to fosse conveniente para todos os clientes. }\end{array}$ & $\begin{array}{l}\text { ZYZ não tem os horários de funcionamento conve- } \\
\text { nientes a todos os clientes. }\end{array}$ \\
\hline 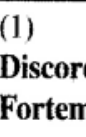 & & 2) (3) & (5) (6) $\quad \begin{array}{r}\text { Concordo } \\
\text { Fortemente }\end{array}$ \\
\hline
\end{tabular}

Tabela 1. O Instrumento SERVQUAL (ABACKERLI et al, 2005) 
As empresas pesquisadas representavam cinco categorias de serviço, a saber: reparo e manutenção de produtos, banco varejista, chamadas telefônicas de longa distância, corretagem de ações e operação de cartão de crédito. Estas categorias de serviço foram escolhidas pelo autor por serem classificadas como representativas do setor de serviços norte-americano.

Foram identificados inicialmente 97 itens, distribuídos pelas 10 dimensões da qualidade, capazes de caracterizar as percepções de qualidade. A escala ou conjunto de 97 itens, relativos à expectativa, e 97 itens relativos à percepção de qualidade foi refinada, em três estágios, coletando-se 200 respondentes adultos igualmente divididos entre homens e mulheres.

Cada item inicial foi refeito no formato de duas declarações. Uma fazia referência à expectativa do serviço e a outra à percepção de qualidade da empresa em questão. Aproximadamente metade dos itens foi escrita no formato afirmativo e a outra metade, negativamente, tendo seus valores de escala Lickert invertidos.

Foi feito um refinamento deste instrumento e chegou-se a um resultado de cinco dimensões da qualidade e composta por um total de 22 itens.

As cinco dimensões da qualidade resultantes deste refinamento da escala foram as seguintes:

- Confiabilidade: habilidade de prestar o serviço com exatidão;

- Presteza: disposição em ajudar os clientes e fornecer o serviço com presteza e prontidão;

- Segurança: conhecimento dos funcionários e suas habilidades em demonstrar confiança;

- Empatia: grau de cuidado e atenção pessoal dispensado aos clientes; e

- Aspectos Tangíveis: aparência das instalações, equipamentos, pessoal envolvido e material de comunicação.

Os vinte e dois itens da Tabela 1 são distribuídos pelas cinco dimensões acima e não são descritos genericamente, e sim, por meio de afirmações e negações, representando características específicas para cada dimensão. 


\subsubsection{A aplicação do instrumento SERVQUAL no serviço público}

O modelo SERVQUAL, conforme visto no capítulo anterior, foi elaborado com base nos serviços prestados pela iniciativa privada e por isso totalmente voltado para empresas desse setor.

Pesquisa no sítio da internet Google permitiu constatar as poucas iniciativas de aplicação do modelo em serviços públicos. Nas referências indicadas pelo sítio de busca, em pesquisa feita no dia 09 de novembro de 2008 (http://www.google.com.br/search?hl=pt$B R \& q=a p l i c a \% C 3 \% A 7 \% C 3 \% A 3 o+d o+$ servqual + no + servi $\% C 3 \% A 7 o+p \% C 3 \% B A b l i c o \& m e$ $t a=)$, é possível encontrar somente uma aplicação do modelo no México para a avaliação de serviços hospitalares e um artigo do Brasil, que relata a experiência do Estado do Rio Grande do Norte, em serviços escolares. Sendo que este último muito recente, datando o ano de 2008.

Assim, mesmo considerando as limitações desta busca, pressupõe-se que o instrumento SERVQUAL ainda não foi devidamente adaptado e comprovadamente testado na administração pública.

Dessa maneira é importante levantar que o instrumento pode trazer falhas quando aplicado para o serviço público, no que tange a avaliação das cinco dimensões da qualidade que, como já estudado no capítulo anterior, são: confiabilidade, presteza, garantia, empatia e aspectos tangíveis.

É possível esperar que o item aspectos tangíveis a maior falha, pois é sabido que a administração pública brasileira ainda sofre com a problemática do sucateamento de suas instalações, equipamentos e material de comunicação, assim como o despreparo dos servidores públicos mais antigos, advindos do período anterior à implantação do gerencialismo.

Todavia, a aplicação do instrumento no serviço público pode trazer ganhos imediatos, pois possibilitaria saber qual a expectativas dos usuários dos serviços públicos, bem como a avaliação que faz hoje dos serviços prestados, apesar de todos os conhecidos problema enfrentados pela Administração Pública brasileira. 


\section{METODOLOGIA}

\subsection{Tipo de pesquisa}

A pesquisa foi realizada na abordagem quantitativa. A escolha motivou-se pela necessidade de formação de um quadro de referência, por meio da aplicação de um único instrumento de pesquisa, visando revelar a realidade organizacional através do estabelecimento de relações entre as variáveis presentes no instrumento.

O objetivo da pesquisa era mensurar a percepção dos usuários dos serviços da Secretaria dos Órgãos Julgadores do Superior Tribunal de Justiça quanto à qualidade, confiabilidade, presteza e segurança dos serviços prestados.

\subsection{Contextualização do ambiente da pesquisa}

Criado pela Constituição Federal de 1988, o Superior Tribunal de Justiça (STJ) é a corte responsável por uniformizar a interpretação da lei federal em todo o Brasil, seguindo os princípios constitucionais e a garantia e defesa do Estado de Direito.

O STJ é a última instância da Justiça brasileira para as causas infraconstitucionais, ou seja, àquelas não relacionadas diretamente com a interpretação da Constituição. Como órgão de convergência da Justiça comum, aprecia causas oriundas de todo o território nacional, em todas as vertentes jurisdicionais não-especializadas.

Sua competência está prevista no art. 105 da Constituição Federal, que estabelece os processos que têm início no STJ (originários) e os casos em que o Tribunal age como órgão de revisão, inclusive nos julgamentos de recursos especiais.

O STJ julga crimes comuns praticados por governadores dos Estados e do Distrito Federal; crimes comuns e de responsabilidade de desembargadores dos tribunais de justiça e de conselheiros dos tribunais de contas estaduais, dos membros dos tribunais regionais federais, eleitorais e do Trabalho.

Julga também habeas-corpus que envolva essas autoridades ou ministros de Estado, exceto em casos relativos à Justiça eleitoral. Pode apreciar, ainda, recursos contra habeascorpus concedidos ou negados por tribunais regionais federais ou dos estados, bem como causas decididas nessas instâncias, sempre que envolverem lei federal.

Em 2005, como parte da reforma do Judiciário, o STJ assumiu também a competência para analisar a concessão de cartas rogatórias (são solicitações de um tribunal estrangeiro para que a justiça nacional coopere na realização de certos atos que interessem àquelas justiças, 
tais como citações, depoimentos, exames e outras diligências) e processar e julgar a homologação de sentenças estrangeiras.

Para que possa cumprir melhor a missão institucional que lhe foi dada na Constituição Federal de 1988, o Superior Tribunal de Justiça (STJ) foi organizado pelo critério da especialização. Os órgãos julgadores foram divididos em três seções de julgamento, cada uma delas composta por duas turmas, as quais analisam e julgam matérias de acordo com a natureza da causa submetida à apreciação. Acima delas está a Corte Especial, órgão julgador máximo do Tribunal. (BRASIL, 1989). As funções administrativas do STJ são exercidas pelo Plenário, integrado pela totalidade dos ministros da Casa.

O STJ completou 19 anos em 2008. Diante da grande repercussão de suas decisões e de sua importância no cenário jurídico brasileiro, é difícil compreender que sua trajetória seja tão curta, todavia há uma explicação. Na verdade, o STJ é fruto de uma gama de debates políticos e acadêmicos que permearam todo o século XX e tiveram como auge a Constituição Federal de 1988.

O STJ é descendente direto de uma outra instituição surgida há 60 anos: o Tribunal Federal de Recursos (TFR). Tal como o STJ, o TFR foi uma das grandes novidades de uma carta constitucional que surgia após um longo período de exceção democrática no país: o Estado Novo. (BRASIL, 1989)

Pouco mais de 20 anos após a instalação do TFR, o mundo jurídico brasileiro iniciou as discussões para tornar a corte mais atuante principalmente em função da sobrecarga de julgamentos no Supremo Tribunal Federal. A primeira iniciativa legal no sentido de se criar uma nova corte partiu dos próprios magistrados do TFR. A instituição, em 1976, mandou a minuta de um projeto de lei ao Congresso para a instituição do Supremo Tribunal de Justiça, que seria a última instância das leis infraconstitucionais do país, deixando para o STF a prerrogativa exclusiva de controlar a constitucionalidade. (BRASIL, 1989)

Somente no recente período de redemocratização, em 1985, a iniciativa ganhou força. Atentos à possibilidade de convocação de uma Assembléia Constituinte, os magistrados do TFR resolveram se mobilizar. No ano seguinte, com o início dos trabalhos da Assembléia, o TFR formou uma comissão de magistrados para atuar junto aos parlamentares. (BRASIL, 1989)

O empenho dos magistrados resultou em uma verdadeira revolução no Judiciário a partir da promulgação da Constituição, em 5 de outubro de 1988. Símbolo mor dessa transformação foi a criação do STJ, última instância das leis infraconstitucionais tanto no âmbito da Justiça Federal como no da estadual. (BRASIL, 1989) 
O STJ começou a funcionar em abril de 1989 - ano em que julgou pouco mais de três mil processos. Em seus 19 anos de existência, o Tribunal ganhou uma nova sede em 1995 e viu seu número de julgados crescer exponencialmente. No total, o Tribunal já contabiliza mais de 3 milhões de julgamentos ao longo de sua história.

Hoje o STJ tem como missão:

Processar e julgar as matérias de sua competência originária e recursal, assegurando a uniformidade na interpretação das normas infraconstitucionais e oferecendo ao jurisdicionado uma prestação acessível, rápida e efetiva (Brasil, 2006, p. 06).

E como visão de futuro:

"ser reconhecido pela sociedade como modelo na garantia de uma justiça acessível, rápida e efetiva” (Brasil, 2006, p. 06).

\subsubsection{A Secretaria dos Órgãos Julgadores}

A Secretaria dos Órgãos Julgadores - SOJ - é a unidade do Superior Tribunal de Justiça que tem como funções dar apoio à atividade judicante, auxiliar no processamento e julgamento dos processos de competência originária e recursal do STJ, prestar apoio aos advogados. É responsável também por proceder ao apanhamento taquigráfico nas sessões de julgamento e eventos realizados pelo Tribunal e pelo Conselho da Justiça Federal, expedir as comunicações oficiais, promover a execução judicial dos feitos de competência originária, publicar os acórdãos e decisões e cumprir os mandados judiciais.

A SOJ é composta por:

- Gabinete do Secretário: coordena as atividades de toda a unidade.

- 01 Seção de Apoio aos Advogados: responsável por subsidiar os advogados de informações e materiais que facilitem o acesso aos processos e decisões do STJ.

- 01 Seção de Recurso Extraordinário: faz o processamento e encaminha os recursos extraordinários que devem ser encaminhados ao Supremo Tribunal Federal.

- 01 Coordenadoria de Taquigrafia: responsável pelo apanhamento e transcrição taquigráfica das sessões de julgamento e eventos realizados pelo Tribunal e pelo Conselho da Justiça Federal.

- 01 Coordenadoria de Execução Judicial: procede a execução judicial dos feitos de competência originária do STJ.

- 10 Coordenadorias de Órgão Julgador (divididas conforme especialização de matéria julgada): responsáveis por apoiar a atividade judicante, auxiliar no processamento e julgamento dos processos de competência originária e recursal do Tribunal, expedir as comunicações oficiais e publicar os acórdãos e decisões proferidas pelo STJ. 
É por intermédio dessas unidades que se dão a maior parte dos atendimentos prestados ao público externo que procura o Superior Tribunal de Justiça, além de todas as atividades acima elencadas.

\subsection{População e Amostra}

A população da pesquisa compreendeu operadores do direito e cidadãos que utilizam os serviços da Secretaria dos Órgãos Julgadores do Superior Tribunal de Justiça de forma presencial, ou seja, que comparecem ao Tribunal para obter o serviço desejado.

Essa população é variável, por isso a base será feita sobre o número de atendimentos que são realizados pela SOJ. Esse número, no mês de junho de 2008 foi de: 10920.

O questionário foi disponibilizado nas unidades da Secretaria dos Órgãos Julgadores, no período entre 20 de outubro de 2008 e 19 de dezembro de 2008.

O número de respostas aos questionários foi de 111.

\subsection{Instrumento}

O instrumento quantitativo aplicado foi o questionário SERVQUAL (PARASURAMAN et al, apud ABACKERLI et al, 2005) - ANEXO 1 - composto de dois questionários, cada um com vinte duas afirmativas. O primeiro questionário visa obter as expectativas dos clientes e o segundo tem por objetivo obter a percepção dos clientes em relação aos serviços prestados pelo Superior Tribunal de Justiça.

Todas as questões do instrumento são fechadas e respondidas numa escala de 1 (discordo totalmente) a 7 (concordo plenamente). O texto de cada afirmativa presente no questionário foi devidamente adaptado para a realidade dos órgãos judicantes e da SOJ. Todas as questões presentes no instrumento original foram apresentadas aos respondentes.

\subsection{Procedimentos de Coleta de Dados}

As informações foram coletadas, através dos questionários, nos locais de atendimento das unidades da Secretaria dos Órgãos Julgadores.

O pesquisado, de forma individual, usou o tempo de espera que existe entre fazer o pedido do serviço e a entrega deste para responder as questões propostas. A aplicação foi realizada pelos próprios atendentes dos locais acima descritos. 


\subsection{Procedimentos de Análise dos Dados}

A análise dos dados foi realizada com base nos preceitos do instrumento SERVQUAL (PARASURAMAN et al, apud ABACKERLI et al, 2005). Para um melhor entendimento, tanto dos dados como dos resultados, são apresentados os resultados obtidos em cada afirmativa presente nos questionários. A seguir, dividiu-se o objeto conforme as dimensões da qualidade correspondentes, analisando cada gap. Ao final o objeto foi reconstruído, possibilitando a análise do gap final (ou gap da qualidade) dos serviços prestados. 


\section{RESULTADOS}

O instrumento SERVQUAL (Parasuraman et al, apud ABACKERLI et al, 2005) adaptado foi aplicado nos órgãos de compreendem a Secretaria dos Órgãos Julgadores do Superior Tribunal de Justiça, conforme especificado no item 3 deste trabalho.

Ao todo, o instrumento obteve 111 respondentes. Considerando-se os objetivos da pesquisa, que procura descrever as expectativas e percepção quanto a qualidade dos serviços prestados pela SOJ, sem ter a pretensão de inferir as causas dessas, este número já permitiu um estudo das expectativas e percepções da qualidade mostradas pelos usuários dos órgãos julgadores quanto aos serviços oferecidos pela SOJ.

\subsection{Números da expectativa}

A medida da expectativa na qualidade em serviços corresponde àquilo que o usuário espera de um serviço que já utiliza ou um dia venha a utilizar, ou seja, é aquilo que gostaríamos de encontrar quando procuramos uma prestação de serviços.

Carvalho e Paladini (2005) consideram que clientes são diferentes e têm necessidades/desejos diferentes; por isso só podemos atendê-los de maneira adequada naquilo que desejam, se houver um entendimento de quais são os aspectos de desempenho a serem trabalhados para atender suas expectativas.

Abaixo é apresentada uma tabela com as médias apresentadas em cada questão quanto às expectativas apresentadas pelos usuários dos serviços prestados pela SOJ.

\begin{tabular}{l|c|}
\hline AFIRMATIVA (Expectativa) & $\begin{array}{c}\text { MÉDIA } \\
\text { EXPETATIVA }\end{array}$ \\
\hline $\begin{array}{l}\text { Um serviço de prestação jurisdicional deveria contar com equipamentos } \\
\text { modernos que possibilitassem auto-atendimento e atendimento remoto aos } \\
\text { seus usuários. }\end{array}$ & $\mathbf{6 , 5 1}$ \\
Quando um serviço judicante promete fazer algo em certo tempo, deveria \\
fazê-lo. \\
$\begin{array}{l}\text { Os servidores de um órgão judicante deveriam prestar serviços } \\
\text { prontamente, de modo que seus usuários esperem pelo serviço o menor } \\
\text { tempo possível. }\end{array}$ \\
$\begin{array}{l}\text { O comportamento dos servidores de um órgão judicante do STJ deveria } \\
\text { inspirar confiança em você. }\end{array}$ \\
$\begin{array}{l}\text { Um serviço prestado por um órgão judicante deveria dar atenção individual } \\
\text { ao usuário. }\end{array}$
\end{tabular}


As instalações físicas de um órgão judicante deveriam ser visualmente atrativas.

Quando os usuários de um órgão judicante têm algum problema, os responsáveis pelo serviço deveriam mostrar interesse sincero em resolvêlo.

Os servidores de um órgão judicante deveriam prestar serviços prontamente.

Você deveria se sentir seguro em suas utilizações do serviço de um órgão judicante.

Os servidores de um órgão judicante deveriam dar atenção individualizada aos usuários.

Os servidores de um órgão judicante deveriam estar bem vestidos e cuidar de sua aparência.

Um serviço de um órgão judicante deveria ser executado corretamente já na primeira vez, evitando assim o retorno de seus usuários para a correção de algum serviço prestado.

Os servidores de um órgão judicante nunca devem estar demasiadamente ocupados para atender uma solicitação.

Os servidores de um órgão judicante deveriam ser realmente gentis com você.

Um órgão judicante deveria levar a sério os interesses mais importantes do usuário.

Os materiais associados a um serviço prestado por um órgão judicante (como folhetos explicativos) deveriam possuir apelo visual.

Um órgão judicante deveria fornecer o serviço requerido pelo usuário no tempo prometido.

Os servidores de um órgão judicante deveriam ter o conhecimento necessário para responder seus questionamentos.

Os servidores de um órgão judicante deveriam compreender as suas necessidades específicas.

Um órgão judicante deveria ter horário de atendimento conveniente.

Um órgão judicante deveria manter seus usuários informados acerca de quando os serviços serão executados.

\begin{tabular}{|c|}
\hline 5,88 \\
\hline 6,52 \\
\hline 6,33 \\
\hline 6,49 \\
\hline 5,88 \\
\hline 5,28 \\
\hline 6,50 \\
\hline 5,98 \\
\hline 6,29 \\
\hline 6,38 \\
\hline 5,80 \\
\hline 6,47 \\
\hline 6,36 \\
\hline 6,00 \\
\hline 6,44 \\
\hline 6,41 \\
\hline
\end{tabular}

Tabela 2: Média das respostas - Questionário Expectativa

\subsection{Números da percepção}

Carvalho e Paladini (2005) afirmam que as situações de contato entre o cliente e a organização prestadora de serviço interferem positivamente e negativamente na percepção da qualidade pelo cliente. Sendo assim, a medida percepção na qualidade da prestação de 
serviços vem aferir como os usuários de um determinado serviço se sentem quando recebem (utilizam) o serviço.

Abaixo é apresentada a tabela com as médias obtidas no questionário que afere a percepção da qualidade do serviço prestado. modernos que possibilitam o auto-atendimento e atendimento remoto aos seus usuários.

Quando um órgão julgador do STJ promete fazer algo em certo tempo, realmente o faz.

Os servidores dos órgãos julgadores do STJ prestam serviços prontamente de modo que seus usuários esperem pelo serviço o menor tempo possível.

O comportamento dos servidores dos órgãos julgadores do STJ inspiram confiança em você.

Os órgãos julgadores do STJ dão atenção individual ao usuário.

As instalações físicas dos órgãos julgadores do STJ são visualmente atrativas.

Quando o usuário dos órgãos julgadores do STJ tem algum problema, os responsáveis pelo serviço mostram interesse sincero em resolvê-lo.

Os servidores dos órgãos julgadores do STJ estão sempre dispostos a ajudálo.

Você se sente seguro em suas utilizações do serviço dos órgãos julgadores do STJ.

Os servidores dos órgãos julgadores do STJ dão atenção individualizada a você enquanto usuário dos serviços prestados.

Os servidores dos órgãos julgadores do STJ são bem vestidos e cuidam de sua aparência.

Os serviços dos órgãos julgadores do STJ são executados corretamente já na primeira vez, evitando assim que seu retorno para corrigir o serviço prestado.

Os servidores dos órgãos julgadores do STJ nunca estão demasiadamente ocupados para atender sua solicitação.

Os servidores dos órgãos julgadores do STJ são realmente gentis com você.

Os órgãos julgadores do STJ levam os interesses mais importantes do usuário a sério.

Os materiais associados aos órgãos julgadores do STJ (como folhetos explicativos) possuem boa comunicação e apelo visual.

5,91

5,62

5,86

6,13

5,70

5,15

5,94

5,91

6,10

5,82

5,96

5,83

5,42

6,07

6,01

5,51 
Os órgãos julgadores do STJ fornecem o serviço no tempo prometido.

Os servidores dos órgãos julgadores do STJ têm o conhecimento necessário para responder seus questionamentos.

Os servidores dos órgãos do STJ compreendem suas necessidades específicas.

Os órgãos julgadores do STJ possuem horário de atendimento conveniente.

Os órgãos julgadores do STJ mantêm seus usuários informados acerca de quando os serviços serão executados.

\begin{tabular}{|c|}
5,77 \\
6,02 \\
5,87 \\
6,39 \\
5,93
\end{tabular}

Tabela 3: Média das respostas - Questionário Percepção

\subsection{Números por dimensão da qualidade e gap final}

Parasuraman et al (apud ABACKERLI et al, 2005) diz que as dimensões da qualidade representam os fatores críticos da prestação de um serviço, que podem causar a discrepância entre expectativa e desempenho.

Sendo assim, para calcular essa possível discrepância condensaram-se os dados obtidos na pesquisa separando os resultados obtidos em cada afirmativa conforme a dimensão da qualidade que representa. Após, calculou-se cada "gap” (ou hiato) da dimensão, conforme apresentado na tabela abaixo.

A tabela apresenta também o “gap” final da pesquisa.

\begin{tabular}{lccc}
\hline \multicolumn{1}{c}{ DIMENSÃO } & EXPECTATIVA & PERCEPÇÃO & HIATO \\
\hline Aspectos Tangíveis & 6,12 & 5,64 & 0,48 \\
Confiabilidade & 6,52 & 5,79 & 0,73 \\
Presteza & 6,32 & 5,82 & 0,50 \\
Segurança & 6,32 & 6,05 & 0,27 \\
Empatia & 6,12 & 5,98 & 0,14 \\
\hline
\end{tabular}

\footnotetext{
Tabela 4: Médias por dimensão da qualidade e gap final.
} 


\section{ANÁLISE DOS RESULTADOS}

Analisar e discutir os resultados de uma pesquisa é transmitir estes na forma de raciocínios, cabendo a esse raciocínio encadear juízos e conceitos, simbolizados por palavras no nível da expressão lingüística. (GONÇALVES, 2005). A autora coloca ainda que na análise dos resultados o objeto de estudo é decomposto em suas partes constitutivas, tornando-se assim, simples aquilo que era composto e complexo. E após é recomposto, constituindo-se a sua totalidade.

Seguindo este preceito defendido por Gonçalves (2005), analisaremos os dados, primeiro em suas partes, ou seja, em cada dimensão da qualidade e após a análise do resultado conjunto.

\subsection{Dimensão 1: aspectos tangíveis}

Como já referenciado no trabalho, a dimensão que avalia os aspectos tangíveis visa medir a percepção dos usuários quanto à aparência das instalações, equipamentos, pessoal envolvido e material de comunicação utilizados e/ou disponíveis durante a prestação dos serviços.

\subsubsection{Expectativa dos usuários nos aspectos tangíveis}

Abaixo se apresenta a tabela com as questões disponibilizadas aos usuários nos questionários da vertente expectativa, a média das notas atribuídas, a nota máxima apresentada, a menor nota atribuída a cada questão e finalmente a moda (nota mais freqüente).

\begin{tabular}{lcccc}
\hline \multicolumn{1}{c}{ QUESTÃo } & $\begin{array}{c}\text { MÉDIA DAS } \\
\text { NOTAS }\end{array}$ & $\begin{array}{c}\text { NOTA } \\
\text { MÁXIMA }\end{array}$ & $\begin{array}{c}\text { NOTA } \\
\text { MÍNIMA }\end{array}$ & MODA \\
\hline $\begin{array}{l}\text { Um serviço de prestação jurisdicional } \\
\text { deveria contar com equipamentos } \\
\text { modernos que possibilitassem auto- }\end{array}$ & $\mathbf{6 , 5 1}$ & 7 & 3 & 7 \\
$\begin{array}{l}\text { atendimento e atendimento remoto aos } \\
\text { seus usuários. }\end{array}$ & & & \\
$\begin{array}{l}\text { As instalações físicas de um órgão } \\
\text { judicante deveriam ser visualmente } \\
\text { atrativas }\end{array}$ & $\mathbf{5 , 8 8}$ & $\mathbf{7}$ & $\mathbf{7}$ \\
$\begin{array}{l}\text { Os servidores de um órgão judicante } \\
\text { deveriam estar bem vestidos e cuidar de }\end{array}$ & $\mathbf{6 , 2 8}$ & 7 & $\mathbf{2}$ & 7 \\
\hline
\end{tabular}


sua aparência.

Os materiais associados a um serviço

prestado por um órgão judicante (como

folhetos explicativos) deveriam possuir

apelo visual.

Tabela 5: Expectativas dos usuários - dimensão aspectos tangíveis.

Os dados apresentados na vertente expectativa dos aspectos tangíveis permitem afirmar que as expectativas dos usuários dos serviços da Secretaria dos Órgãos Julgadores quanto aos serviços prestados é alta. Essa afirmativa é embasada pelas médias obtidas em cada sentença e pela nota máxima apresentada (7) em todas as questões. Essa nota também é a moda.

Entre as médias das notas obtidas, a afirmativa que avalia a qualidade dos equipamentos e possíveis atendimentos remotos feitos pelos órgãos julgadores (um serviço de prestação jurisdicional deveria contar com equipamentos modernos que possibilitassem autoatendimento e atendimento remoto aos seus usuários) é a que obteve a maior média $(6,51)$. Isso nos mostra que os usuários têm alta expectativa quanto à possibilidade de contar com equipamentos modernos que facilitam seu atendimento e por vezes que possam atender a suas necessidades de outro local, sem necessariamente precisarem ir ao Tribunal para obter o serviço do qual está precisando naquele momento.

Os usuários não consideram tão importante ter um material de comunicação de boa qualidade, questão avaliada pela afirmativa "os materiais associados a um serviço prestado por um órgão judicante (como folhetos explicativos) deveriam possuir apelo visual”, pois a média das notas atribuídas pelos usuários foi 5,80. Essa foi a média mais baixa obtida pelas afirmativas da dimensão aspectos tangíveis.

A segunda expectativa mais baixa apresentada pelas respostas dos usuários é a que diz respeito às instalações físicas do órgão julgador $(5,88)$. Ou seja, os usuários, comparando com outros pontos da dimensão, dão menos importância à beleza e atratividade das instalações físicas do órgão.

Já a segunda maior média apresentada é a que avalia a aparência dos servidores que fazem o atendimento dos usuários no órgão julgador. A afirmativa (os servidores de um órgão judicante deveriam estar bem vestidos e cuidar de sua aparência) obteve a média de 6,28. Sendo assim é possível afirmar que os usuários dos serviços esperam encontrar atendentes devidamente trajados e bem apessoados quando chega a uma unidade de atendimento para solicitar algum serviço. 


\subsubsection{Percepção dos usuários nos aspectos tangíveis}

Abaixo se apresenta a tabela com as das questões apresentadas aos usuários nos questionários na vertente percepção, a média das notas atribuídas, a nota máxima apresentada, a menor nota atribuída a cada questão e finalmente a moda.

\begin{tabular}{|c|c|c|c|c|}
\hline QUESTÃO & $\begin{array}{c}\text { MÉDIA DAS } \\
\text { NOTAS }\end{array}$ & $\begin{array}{c}\text { NOTA } \\
\text { MÁXIMA }\end{array}$ & $\begin{array}{c}\text { NOTA } \\
\text { MÍNIMA }\end{array}$ & MODA \\
\hline $\begin{array}{l}\text { O serviço prestado pelos órgãos } \\
\text { julgadores do STJ utiliza equipamentos } \\
\text { modernos que possibilitam o auto- } \\
\text { atendimento e atendimento remoto aos } \\
\text { seus usuários. }\end{array}$ & 5,91 & 7 & 2 & 7 \\
\hline $\begin{array}{l}\text { As instalações físicas dos órgãos } \\
\text { julgadores do STJ são visualmente } \\
\text { atrativas. }\end{array}$ & 5,15 & 7 & 1 & 7 e 5 \\
\hline $\begin{array}{l}\text { Os servidores dos órgãos julgadores do } \\
\text { STJ são bem vestidos e cuidam de sua } \\
\text { aparência. }\end{array}$ & 5,96 & 7 & 3 & 6 \\
\hline $\begin{array}{l}\text { Os materiais associados aos órgãos } \\
\text { julgadores do STJ (como folhetos } \\
\text { explicativos) possuem boa comunicação e } \\
\text { apelo visual. }\end{array}$ & 5,51 & 7 & 1 & 6 e 5 \\
\hline
\end{tabular}

Tabela 6: Percepção dos usuários - dimensão aspectos tangíveis.

A primeira afirmativa da vertente percepção (o serviço prestado pelos órgãos julgadores do STJ utiliza equipamentos modernos que possibilitam o auto-atendimento e atendimento remoto aos seus usuários) obteve como média 5,91. Essa foi a segunda maior nota da dimensão quanto à percepção dos usuários sobre a qualidade dos serviços prestados. Com base nessa média e nas notas predominantes, é possível dizer que os usuários têm uma boa percepção dos serviços prestados em relação aos equipamentos utilizados na prestação de serviços e nas possibilidades hoje existentes de atendimento remoto.

A maior nota recebida na dimensão quanto à percepção foi na afirmativa "os servidores dos órgãos julgadores do STJ são bem vestidos e cuidam de sua aparência”, com a média de 5,96. Se comparar a média recebida com a nota mais freqüente apresentada na afirmativa é possível afirmarmos que houve pouca variação nas notas recebidas pela afirmativa, conseqüentemente é possível inferir que a maior parte dos usuários tem a mesma 
percepção sobre o item avaliado, ou seja, na hora de obter um serviço encontram servidores bem vestidos e que cuidam da aparência para prestar o serviço.

O item com menor média de percepção foi o da afirmativa que avalia as instalações físicas das unidades de atendimento da Secretaria dos Órgãos Julgadores. A média das notas ficou em 5,15. Aconteceu ainda na afirmativa a igual ocorrência de notas 5 e 7 (a nota 6 só apresentou duas ocorrências a menos que estas duas), com nota mínima em 1. Essa homogeneidade na distribuição das respostas dadas pelos usuários permite inferir que os usuários têm percepções bastante diferentes em relação às instalações físicas dos locais em que são realizados os atendimentos, parecendo pertencer a dois grupos bem definidos em relação a este item.

A afirmação "os materiais associados aos órgãos julgadores do STJ (como folhetos explicativos) possuem boa comunicação e apelo visual” obteve uma média de 5,51. As notas mais freqüentes (moda), com o mesmo número de ocorrências, foram 6 e 5. Dentre as percepções apresentadas pelos usuários na dimensão dos aspectos tangíveis, essa foi a afirmação com a segunda menor nota. E ainda, há uma uniformidade na percepção dos usuários.

\subsubsection{GAP da dimensão aspectos tangíveis}

A partir da análise das médias de cada questão analisa-se a diferença entre as expectativas dos usuários e a percepção deles em relação aos serviços prestados pela Secretaria dos Órgãos Julgadores, que se denomina GAP da qualidade.

Abaixo segue uma tabela que mostra o GAP de cada afirmativa e o GAP final da dimensão aspectos tangíveis.

\begin{tabular}{lccc}
\hline \multicolumn{1}{c}{ ITEM } & EXPECTATIVA & PERCEPÇÃO & GAP \\
\hline Equipamentos & $\mathbf{6 , 5 1}$ & 5,91 & $\mathbf{0 , 6}$ \\
Instalações Físicas & 5,88 & 5,15 & $\mathbf{0 , 7 3}$ \\
Aparência dos Servidores & $\mathbf{6 , 2 8}$ & 5,96 & $\mathbf{0 , 3 2}$ \\
Material de Comunicação & 5,80 & 5,51 & $\mathbf{0 , 2 9}$ \\
GAP TOTAL & $\mathbf{6 , 1 2}$ & 5,64 & $\mathbf{0 , 4 8}$ \\
\hline
\end{tabular}

Tabela 7: GAPs - dimensão aspectos tangíveis.

A partir do cálculo dos GAPs é possível afirmar que as diferenças entre as expectativas dos usuários e a percepção dos serviços recebidos na dimensão aspectos 
tangíveis é baixa, com um valor médio de 0,48 , ou seja, menos de meio ponto na escala de valores utilizada.

O maior gap de qualidade apresentado na dimensão foi calculado na afirmação que avalia as instalações físicas das unidades de atendimento da SOJ, com o valor de 0,73.

Esses números apresentam uma situação preocupante, pois os dados coletados mostram que os usuários do serviço não possuem uma altíssima expectativa quanto às instalações físicas disponíveis para atendimento (se comparado com as demais afirmativas, a expectativa com as instalações físicas é uma das mais baixas - 5,88). No mesmo caminho seguiu a percepção dos usuários, marcando uma média de apenas 5,15 quanto à aparência, o conforto e a usabilidade das instalações físicas das unidades de atendimento. Dessa maneira é possível afirmar que na dimensão aspectos tangíveis esse é o item que merece bastante atenção por parte dos administradores dos serviços.

O segundo item com maior gap na qualidade do serviço é o que avalia os equipamentos disponíveis para atendimento dos usuários e a possibilidade de atendimento remoto, com um valor de 0,6. Esse número é elevado devido à grande expectativa apresentada pelos usuários (a maior expectativa apresentada na dimensão aspectos tangíveis) - 6,51 - e pode ser considerado pequeno se levar em consideração que para os usuários quanto menos for preciso ir ao Tribunal para obter algum serviço, melhor. É interessante considerar também que todos os respondentes foram usuários que compareceram ao Tribunal para obter o serviço, então podemos imaginar que se os usuários respondentes fossem aqueles que utilizam os serviços remotos a percepção seria ainda mais elevada.

É salutar considerar, por exemplo, que o STJ é o único Tribunal do país que desde 2004 disponibiliza todos os seus julgados na internet, com certificação digital e validade jurídica e que também é possível fazer os mais diferentes pedidos por mensagem eletrônica por isso a percepção dos serviços também foi elevada - 5,91. Todavia, o ideal para os operadores do direito que utilizam os serviços será a implantação do processo digital e a completa disponibilização pelos meios eletrônicos, o que diminuirá facilitará a vida de todos que precisam dos serviços da Secretaria dos Órgãos Julgadores e decrescerá consideravelmente o número de atendimentos presenciais prestados por suas unidades.

Os itens que avaliaram a aparência dos servidores que prestam os serviços e o material de comunicação apresentam gaps com valores próximos, em torno de 0,30 . Sendo que o material de comunicação foi o item consideração menos importante dentre os avaliados na dimensão aspectos tangíveis. Já a aparência dos servidores que prestam o serviço teve tanto 
uma expectativa como uma percepção elevadas, o que faz concluir que é um aspecto importante para o usuário que, contudo, está sendo bem atendido por quem presta o serviço.

\subsection{Dimensão 2: confiabilidade}

Avaliar a dimensão confiabilidade na prestação de um serviço é verificar se o prestador de um serviço consegue fazê-lo com habilidade e exatidão, exatidão essa que advém, por exemplo, no contexto da Secretaria dos Órgãos Julgadores, da correta comunicação de um ato processual para as partes, entrega das cópias corretas dos processos solicitados por um usuário

\subsubsection{Expectativa dos usuários quanto à confiabilidade}

Abaixo se apresenta a tabela com as questões disponibilizadas aos usuários nos questionários da vertente expectativa, a média das notas atribuídas, a nota máxima apresentada, a menor nota atribuída a cada questão e finalmente a nota mais freqüente.

\begin{tabular}{lcccc}
\hline \multicolumn{1}{c}{ QUESTÃo } & $\begin{array}{c}\text { MÉDIA DAS } \\
\text { NOTAS }\end{array}$ & $\begin{array}{c}\text { NOTA } \\
\text { MÁXIMA }\end{array}$ & $\begin{array}{c}\text { NOTA } \\
\text { MÍNIMA }\end{array}$ & MODA \\
\hline $\begin{array}{l}\text { Quando um serviço judicante promete } \\
\text { fazer algo em certo tempo, deveria fazê-lo. }\end{array}$ & $\mathbf{6 , 5 9}$ & 7 & 3 & 7 \\
$\begin{array}{l}\text { Quando os usuários de um órgão judicante } \\
\text { têm algum problema, os responsáveis pelo } \\
\text { serviço deveriam mostrar interesse sincero } \\
\text { em resolvê-lo. }\end{array}$ & $\mathbf{6 , 5 2}$ & 7 & 3 & 7 \\
$\begin{array}{l}\text { Um serviço de um órgão judicante deveria } \\
\text { ser executado corretamente já na primeira } \\
\text { vez, evitando assim o retorno de seus }\end{array}$ & $\mathbf{6 , 5 0}$ & 7 & 3 & 7 \\
$\begin{array}{l}\text { usuários para a correção de algum serviço } \\
\text { prestado. }\end{array}$ & & & & \\
\hline $\begin{array}{l}\text { Um órgão judicante deveria fornecer o } \\
\text { serviço requerido pelo usuário no tempo } \\
\text { prometido. }\end{array}$ & $\mathbf{6 , 4 7}$ & 7 & 3 & 7 \\
\hline
\end{tabular}

Tabela 8: Expectativas dos usuários - dimensão confiabilidade.

Os dados apresentados na vertente expectativa da dimensão confiabilidade mostram claramente a altíssima expectativa dos usuários dos serviços dos órgãos judicantes quando a habilidade do prestador em executar corretamente o pedido solicitado. 
Essa alta expectativa pode ser compreendida diante de alta complexidade e importância dos julgamentos proferidos pelo Superior Tribunal de Justiça, que são viabilizados e operacionalizados pelos órgãos avaliados na pesquisa, como por exemplo, a decisão de um Governador de Estado ser, ou deixar de ser, preso por ter cometido um homicídio

Uma característica importante a ser analisada é a homogeneidade das notas atribuídas a todas as questões apresentadas aos usuários quanto à necessidade de se prestar um serviço confiável. A diferença entre a maior média $(6,59)$ e a menor média $(6,47)$ é de apenas 0,12 pontos na escala de notas utilizada.

As notas máximas, mínimas e a moda também são exatamente iguais em todas as afirmativas.

Sendo assim, é fácil afirmar que para os usuários é extremamente importante que os serviços sejam prestados no tempo prometido, de forma correta e que os possíveis problemas sejam resolvidos da forma mais rápida possível.

\subsubsection{Percepção dos usuários quanto à confiabilidade}

Abaixo se apresenta a tabela com as das questões apresentadas aos usuários nos questionários na vertente percepção, a média das notas atribuídas, a nota máxima apresentada, a menor nota atribuída a cada questão e finalmente a nota mais freqüente.

\begin{tabular}{|c|c|c|c|c|}
\hline QUESTÃO & $\begin{array}{l}\text { MÉDIA DAS } \\
\text { NOTAS }\end{array}$ & $\begin{array}{c}\text { NOTA } \\
\text { MÁXIMA }\end{array}$ & $\begin{array}{c}\text { NOTA } \\
\text { MÍNIMA }\end{array}$ & MODA \\
\hline $\begin{array}{l}\text { Quando um órgão julgador do STJ } \\
\text { promete fazer algo em certo tempo, } \\
\text { realmente o faz. }\end{array}$ & 5,62 & 7 & 1 & 6 e 7 \\
\hline $\begin{array}{l}\text { Quando o usuário dos órgãos julgadores } \\
\text { do STJ tem algum problema, os } \\
\text { responsáveis pelo serviço mostram } \\
\text { interesse sincero em resolvê-lo. }\end{array}$ & 5,94 & 7 & 2 & 7 \\
\hline $\begin{array}{l}\text { Os serviços dos órgãos julgadores do STJ } \\
\text { são executados corretamente já na } \\
\text { primeira vez, evitando assim que seu } \\
\text { retorno para corrigir o serviço prestado. }\end{array}$ & 5,83 & 7 & 1 & 7 \\
\hline $\begin{array}{l}\text { Os órgãos julgadores do STJ fornecem o } \\
\text { serviço no tempo prometido. }\end{array}$ & 5,77 & 7 & 1 & 7 e 6 \\
\hline
\end{tabular}

Tabela 9: Percepção dos usuários - dimensão confiabilidade. 
A vertente percepção da dimensão confiabilidade, como a vertente expectativa, também apresentou acentuada homogeneidade nas notas dispensadas pelos usuários em cada afirmativa. A diferença entre a maior média e a menor media é de apenas 0,32 pontos da escala de valor.

Das afirmações propostas aos usuários a que obteve maior média nas notas atribuídas foi a que avalia a disponibilidade dos prestadores dos serviços em resolver os possíveis problemas (quando o usuário dos órgãos julgadores do STJ tem algum problema, os responsáveis pelo serviço mostram interesse sincero em resolvê-lo), com a nota 5,94. Apesar de ter sido a maior nota alcançada pelas afirmativas da dimensão, ela ainda está mais de um ponto abaixo da nota de excelência (7) na escala de mensuração utilizada.

A afirmação “os serviços dos órgãos julgadores do STJ são executados corretamente já na primeira vez, evitando assim que seu retorno para corrigir o serviço prestado” obteve a segunda maior média, 5,83. Esse item procura avaliar o retrabalho, tanto para os usuários como para os prestadores.

A pior percepção dos usuários, na dimensão confiabilidade, está na afirmação “quando um órgão julgador do STJ promete fazer algo em certo tempo, realmente o faz”, com a média 5,62. Essa nota pode ser justificada pelo acumulo e volume de processos julgados todos os anos e a falta de estrutura e mão-de-obra para operacionalizar e dar vazão a todos os julgados. Contudo, a Casa tem como missão institucional a celeridade, e por isso precisa investir para alcançar uma melhor percepção por parte dos usuários quanto ao cumprimento de prazos na prestação de seus serviços.

A segunda nota mais baixa, média 5,77, também diz respeito ao tempo de execução dos serviços: “os órgãos julgadores do STJ fornecem o serviço no tempo prometido”. É possível inferir, então, diante da realidade apresentada que essa nota baixa justifica-se pelo mesmo caminho que a afirmativa avaliada acima.

\subsubsection{GAP da dimensão confiabilidade}

A partir da análise das médias de cada questão analisa-se a diferença entre as expectativas dos usuários e a percepção deles em relação aos serviços prestados pela Secretaria dos Órgãos Julgadores, que se denomina GAP da qualidade.

Abaixo segue uma tabela que mostra o GAP de cada afirmativa e o GAP final da dimensão confiabilidade. 


\begin{tabular}{lccc}
\hline \multicolumn{1}{c}{ ITEM } & EXPECTATIVA & PERCEPÇÃO & GAP \\
\hline Cumprimento da promessa de prazo & 6,59 & 5,62 & 0,97 \\
Interesse na solução de problemas & 6,52 & 5,94 & 0,58 \\
Correção dos serviços prestados & 6,50 & 5,83 & 0,67 \\
Cumprimento de prazos estabelecidos & 6,47 & 5,77 & 0,70 \\
GAP TOTAL & 6,52 & 5,79 & 0,73
\end{tabular}

Tabela 10: GAPs - dimensão confiabilidade.

Com base no cálculo dos gaps apresentados na tabela, é possível afirmar que há um hiato importante - o maior entre todas as dimensões avaliadas pelo instrumento - entre as expectativas e a percepção dos serviços pelos usuários na dimensão confiabilidade. Tendo como GAP total da dimensão o valor de 0,73 pontos.

As afirmações que procuraram mensurar o cumprimento dos prazos acordados entre os prestadores dos serviços, no caso as unidade de atendimento da Secretaria dos Órgãos Julgadores, e os usuários foram as que apresentaram maior diferença entre a expectativa e a percepção dos usuários, com um gap calculado em 0,97 pontos e 0,70 pontos nos itens que avaliaram este aspecto. Essa realidade precisa ser tomada de grande atenção pela administração dos serviços, pois todos os operadores do direito executam suas atividades baseadas nos prazos estabelecidos em lei. Qualquer atraso ou descumprimento de acordos geram prejuízos irreparáveis para os cidadãos e, conseqüentemente, para a sociedade.

Já o menor hiato, ou gap, na dimensão foi o que diz respeito ao interesse dos prestadores de serviços dos órgãos julgadores em solucionar os possíveis problemas que ocorrem com seus usuários. O número obtido foi de 0,58. Entretanto, é importante dizer que a diferença entre o desejável e a realidade ainda existe, mesmo sendo a menor entre os quesitos avaliados na dimensão, o que pode prejudicar a confiança que os usuários têm nos serviços prestados.

A correção dos serviços prestados pelas unidades de atendimentos da Secretaria dos Órgãos Julgadores também foi avaliada. Esse quesito apresenta um gap de 0,67 pontos. Esse número advem de falhas no serviço entregue ao usuário, fazendo com que tanto o usuário como prestador do serviço tenham retrabalho. Sendo que para o usuário é mais desgastante, pois, em muitos momentos, é preciso voltar pessoalmente à unidade de atendimento para solucionar seu problema, podendo gerar estresse e insatisfação. 


\subsection{Dimensão 3: presteza}

Mensurar a dimensão presteza é compreender as expectativas e percepções dos usuários quanto à disposição do prestador do serviço em ajudar os clientes e fornecer o serviço com celeridade e prontidão. Para serviços como os prestados pela SOJ presteza significa viabilizar os serviços solicitados pelo cidadão com agilidade, auxiliando assim para que os direitos e garantias dos cidadãos sejam obtidos com a maior brevidade possível.

\subsubsection{Expectativa dos usuários quanto à presteza}

Abaixo se apresenta a tabela com as afirmações disponibilizadas aos usuários nos questionários da vertente expectativa, a média das notas atribuídas, a nota máxima apresentada, a menor nota atribuída a cada questão e finalmente a nota mais freqüente.

\begin{tabular}{|c|c|c|c|c|}
\hline QUESTÃO & $\begin{array}{l}\text { MÉDIA DAS } \\
\text { NOTAS }\end{array}$ & $\begin{array}{c}\text { NOTA } \\
\text { MÁXIMA }\end{array}$ & $\begin{array}{c}\text { NOTA } \\
\text { MÍNIMA }\end{array}$ & MODA \\
\hline $\begin{array}{l}\text { Os servidores de um órgão judicante } \\
\text { deveriam prestar serviços prontamente, de } \\
\text { modo que seus usuários esperem pelo } \\
\text { serviço o menor tempo possível. }\end{array}$ & 6,48 & 7 & 3 & 7 \\
\hline $\begin{array}{l}\text { Os servidores de um órgão judicante } \\
\text { deveriam prestar serviços prontamente. }\end{array}$ & 6,33 & 7 & 3 & 7 \\
\hline $\begin{array}{l}\text { Os servidores de um órgão judicante } \\
\text { nunca devem estar demasiadamente } \\
\text { ocupados para atender uma solicitação. }\end{array}$ & 5,98 & 7 & 2 & 7 \\
\hline $\begin{array}{l}\text { Os servidores de um órgão judicante } \\
\text { deveriam ter o conhecimento necessário } \\
\text { para responder seus questionamentos. }\end{array}$ & 6,36 & 7 & 1 & 7 \\
\hline $\begin{array}{l}\text { Um órgão judicante deveria manter seus } \\
\text { usuários informados acerca de quando os } \\
\text { serviços serão executados }\end{array}$ & 6,41 & 7 & 2 & 7 \\
\hline
\end{tabular}

Tabela 11: Expectativas dos usuários - dimensão presteza.

A avaliação das expectativas dos usuários na dimensão presteza é realizada por cinco afirmativas, e não quatro, como nas demais dimensões.

Em quatro das afirmativas apresentadas as notas de expectativa ficaram entre 6,33 e 6,48, representando uma alta expectativa dos usuários em relação à presteza dos serviços prestados por um órgão judicante. 
A afirmativa que destoou das demais, em relação às notas atribuídas na escala de valor, foi: "Os servidores de um órgão judicante nunca devem estar demasiadamente ocupados para atender uma solicitação”, com a média 5,98. Esse número permite que se pressuponha uma compreensão por parte dos usuários quanto ao volume de trabalho existente em um órgão judicante do judiciário brasileiro, sendo assim, um pouco paciente quando não pode receber imediatamente o serviço solicitado durante um atendimento.

Entretanto há um contraponto a avaliação acima quando totalizamos a média da afirmação "os servidores de um órgão judicante deveriam prestar serviços prontamente”, de modo que seus usuários esperem pelo serviço o menor tempo possível”. Essa sentença apresenta a maior expectativa $(6,48)$ entre todos os aspectos avaliados na dimensão. Então, se analisarmos a representatividade dessas duas afirmações é possível dizer que os usuários têm a expectativa de ser atendidos prontamente, contudo compreendem se isso não for possível no momento da solicitação devido o volume de trabalho presente nos órgãos julgadores.

Os usuários de serviços de órgãos judicantes esperam que os funcionários responsáveis pelo atendimento tenham um bom conhecimento sobre os assuntos que permeiam os serviços prestados, de modo a responderem seus questionamentos da forma mais breve possível. A afirmativa que avaliou esse aspecto da dimensão totalizou 6,36.

O último ponto avaliado na vertente expectativa da dimensão presteza foi a necessidade que os usuários têm de manterem-se informado sobre o tempo e o andamento dos serviços solicitados. Essa expectativa foi medida pela afirmação: “um órgão judicante deveria manter seus usuários informados acerca de quando os serviços serão executados”, com uma média de 6,41, a segunda maior nota recebida na dimensão.

\subsubsection{Percepção dos usuários quanto à presteza}

Abaixo se apresenta a tabela com as afirmações disponibilizadas aos usuários nos questionários da vertente percepção, a média das notas atribuídas, a nota máxima apresentada, a menor nota atribuída a cada questão e finalmente a nota mais freqüente.

\begin{tabular}{lcccc}
\hline \multicolumn{1}{c}{ QUESTÃO } & $\begin{array}{c}\text { MÉDIA DAS } \\
\text { NOTAS }\end{array}$ & $\begin{array}{c}\text { NOTA } \\
\text { MÁXIMA }\end{array}$ & $\begin{array}{c}\text { NOTA } \\
\text { MíNIMA }\end{array}$ & MODA \\
\hline $\begin{array}{l}\text { Os servidores dos órgãos julgadores do } \\
\text { STJ prestam serviços prontamente de } \\
\text { modo que seus usuários esperem pelo } \\
\text { serviço o menor tempo possível. }\end{array}$ & $\mathbf{5 , 8 6}$ & 7 & $\mathbf{1}$ & $\mathbf{6 e ~} \mathbf{7}$ \\
\hline
\end{tabular}




\begin{tabular}{|c|c|c|c|c|}
\hline $\begin{array}{l}\text { Os servidores dos órgãos julgadores do } \\
\text { STJ estão sempre dispostos a ajudá-lo. }\end{array}$ & 5,91 & 7 & 2 & 7 \\
\hline $\begin{array}{l}\text { Os servidores dos órgãos julgadores do } \\
\text { STJ nunca estão demasiadamente } \\
\text { ocupados para atender sua solicitação. }\end{array}$ & 5,42 & 7 & 1 & 7 e 5 \\
\hline $\begin{array}{l}\text { Os servidores dos órgãos julgadores do } \\
\text { STJ têm o conhecimento necessário para } \\
\text { responder seus questionamentos }\end{array}$ & 6,02 & 7 & 3 & 7 \\
\hline $\begin{array}{l}\text { Os órgãos julgadores do STJ mantêm seus } \\
\text { usuários informados acerca de quando os } \\
\text { serviços serão executados }\end{array}$ & 5,93 & 7 & 1 & 7 \\
\hline
\end{tabular}

Tabela 12: Percepção dos usuários - dimensão presteza.

Na vertente percepção da dimensão presteza a afirmação que recebeu a maior média $(6,02)$ nas notas da escala de valor atribuída pelos usuários dos serviços foi: “os servidores dos órgãos julgadores do STJ têm o conhecimento necessário para responder seus questionamentos”. Nesse caminho é possível concluir que os usuários dos serviços da Secretaria dos Órgãos Julgadores do STJ consideram os funcionários responsáveis por atender os usuários bem instruídos e informados, e conseguem, assim, solucionar as dúvidas apresentadas por aqueles a estes.

Já o aspecto que obteve a pior percepção por parte dos usuários é o que avalia o quão ocupados estão os servidores das unidades de atendimento da SOJ para atender prontamente uma solicitação (os servidores dos órgãos julgadores do STJ nunca estão demasiadamente ocupados para atender sua solicitação). Essa afirmativa obteve a média de 5,42 pontos na escala de valor.

A afirmação que avalia se a Secretaria dos Órgãos Julgadores mantém seus usuários devidamente informados (os órgãos julgadores do STJ mantêm seus usuários informados acerca de quando os serviços serão executados) totalizou a segunda maior média dentre os cinco aspectos avaliados. Sendo assim é possível afirmar que os usuários se consideram informados sobre o andamento dos serviços solicitados.

A sentença que avaliou o tempo de espera, a agilidade para ser atendido nas unidades (os servidores dos órgãos julgadores do STJ prestam serviços prontamente de modo que seus usuários esperem pelo serviço o menor tempo possível), obteve a média de 5,86. Esse número foi muito próximo da média obtida pela afirmação que avalia a disponibilidade do atendente em prestar o serviço aos usuários (os servidores dos órgãos julgadores do STJ estão sempre dispostos a ajudá-lo) - 5,91. Se pensarmos somente na dimensão presteza para avaliar esses 
dois resultados pode afirmar que os usuários têm uma boa percepção sobre os dois aspectos. Contudo é preciso levar em consideração que os números estão consideravelmente abaixo daquele considerado ideal (percepção de excelência), que seria a nota 7 da escala de mensuração, e por isso merecem bastante atenção por parte da administração dos serviços.

\subsubsection{GAP da dimensão presteza}

A partir da análise das médias de cada questão analisa-se a diferença entre as expectativas dos usuários e a percepção deles em relação aos serviços prestados pela Secretaria dos Órgãos Julgadores, que se denomina GAP da qualidade.

Abaixo segue uma tabela que mostra o GAP de cada afirmativa e o GAP final da dimensão presteza.

\begin{tabular}{lccc}
\hline \multicolumn{1}{c}{ ITEM } & EXPECTATIVA & PERCEPÇÃO & GAP \\
\hline $\begin{array}{l}\text { Rapidez no atendimento / tempo de } \\
\text { espera }\end{array}$ & 6,48 & 5,86 & 0,62 \\
\hline $\begin{array}{l}\text { Disposição do servidor em ajudar } \\
\text { Disponibilidade dos servidores }\end{array}$ & 6,33 & 5,91 & 0,42 \\
$\begin{array}{l}\text { Conhecimento dos servidores para tirar } \\
\text { dúvidas e resolver problemas }\end{array}$ & 5,98 & 5,42 & 0,56 \\
\hline $\begin{array}{l}\text { Informações prestadas aos usuários sobre } \\
\text { o andamento dos serviços }\end{array}$ & 6,41 & 6,02 & 0,48 \\
\hline $\begin{array}{l}\text { GAP TOTAL } \\
\text { Tabela 13: GAPs }\end{array}$ & 6,32 & 5,93 & 0,50
\end{tabular}

Tabela 13: GAPs - dimensão presteza.

Calculando a diferença entre as expectativas e as percepções dos usuários obtemos os gaps da qualidade na dimensão presteza. Através do gap total obtido na dimensão $(0,50)$ é possível afirmar que a presteza nos serviços é boa, contudo ainda tem uma diferença de meio ponto da escala de valores entre aquilo que os usuários esperam e aquilo que percebem na hora da prestação dos serviços.

O menor gap apresentado na dimensão $(0,34)$ é o que avalia o conhecimento dos servidores responsáveis pelo atendimento dos usuários em tirar dúvidas e resolver os problemas apresentados por estes. Esse pequeno hiato nos permite concluir que os servidores que trabalham na "linha de frente" das unidades de atendimento da SOJ são bem instruídos e informados, de forma que resolvem os questionamentos apresentados com presteza e celeridade. 
Um dos aspectos avaliados foi a disponibilidade dos servidores em atender os usuários que obteve um gap de 0,56 . Outro aspecto foi a disposição dos servidores para atender os usuários com um gap de 0,42. Assim podemos concluir que os servidores são mais dispostos a atender as solicitações dos usuários do que disponíveis para fazê-las no menor tempo possível. Realidade essa que pode ser novamente explicada pelo volume de trabalho e acumulo de processos no Superior Tribunal de Justiça.

A maior diferença entre expectativa e percepção está na sentença que avaliou a rapidez no atendimento e o tempo de espera dos usuários (0,62). Isso nos diz que os usuários gostariam de ser atendidos num tempo menor do que aquele que ocorre na realidade o que também corrobora a análise anterior quando ao volume de trabalho.

\subsection{Dimensão 4: segurança}

Mensurar a dimensão segurança é entender as expectativas e percepções dos usuários quanto ao conhecimento dos funcionários e suas habilidades em demonstrar e gerar confiança nos usuários dos serviços. Segurança em um serviço judicante significa gerar no usuário a certeza de que os serviços são prestados da forma correta, por pessoas capacitadas, de forma integra e imparcial.

\subsubsection{Expectativa dos usuários quanto à segurança}

Abaixo se apresenta a tabela com as afirmações disponibilizadas aos usuários nos questionários da vertente expectativa quanto à segurança, a média das notas atribuídas, a nota máxima apresentada, a menor nota atribuída a cada questão e finalmente a moda.

\begin{tabular}{lcccc}
\hline \multicolumn{1}{c}{ QUESTÃO } & $\begin{array}{c}\text { MÉDIA DAS } \\
\text { NOTAS }\end{array}$ & $\begin{array}{c}\text { NOTA } \\
\text { MÁXIMA }\end{array}$ & $\begin{array}{c}\text { NOTA } \\
\text { MÍNIMA }\end{array}$ & MODA \\
\hline $\begin{array}{l}\text { O comportamento dos servidores de um } \\
\text { órgão judicante do STJ deveria inspirar } \\
\text { confiança em você }\end{array}$ & $\mathbf{6 , 5 1}$ & 7 & $\mathbf{7}$ & $\mathbf{7}$ \\
$\begin{array}{l}\text { Você deveria se sentir seguro em suas } \\
\text { utilizações do serviço de um órgão } \\
\text { judicante }\end{array}$ & $\mathbf{6 , 4 9}$ & 7 & 3 & $\mathbf{7}$ \\
$\begin{array}{l}\text { Os servidores de um órgão judicante } \\
\text { deveriam ser realmente gentis com você }\end{array}$ & $\mathbf{6 , 2 9}$ & 7 & 2 & 7 \\
\hline
\end{tabular}


Os servidores de um órgão judicante deveriam compreender as suas necessidades específicas

Tabela 14: Expectativas dos usuários - dimensão segurança.

Como nas outras três dimensões avaliadas até agora, os usuários dos serviços têm uma alta expectativa em relação à segurança da prestação de serviços de um órgão judicante.

Na dimensão segurança, o aspecto com maior média de expectativa por parte dos usuários é o que avalia a confiança que os servidores responsáveis pela prestação dos serviços deve inspirar em um usuário (o comportamento dos servidores de um órgão judicante do STJ deveria inspirar confiança em você). A média obtida foi de 6,51, apenas 0,49 pontos abaixo do considerado excelente pela escala de valores (7).

A outra sentença, ou aspecto avaliado, que obteve alta expectativa foi a que afirmava: "você deveria se sentir seguro em suas utilizações do serviço de um órgão judicante” com média de 6,49 (apenas 0,02 pontos a menos que a maior média). Esse resultado é explicado pela grande complexidade e importância dos serviços executados por um órgão judicante para a garantia e efetividade da aplicação do Direito na sociedade.

Os usuários também consideram importante que os servidores de um órgão judicante deveriam ser realmente gentis com os usuários dos serviços, obtendo uma média de 6,29 na vertente expectativa da dimensão segurança.

Já a menor expectativa apresentada está na afirmação “os servidores de um órgão judicante deveriam compreender as suas necessidades específicas” com uma média de 6,0 pontos na escala de valor. Apesar de ser o menor número apresentado nas expectativas da dimensão, é ainda um valor alto dentro da escala de valores apresentadas aos usuários, e por isso merece atenção por parte daqueles que prestam os serviços.

\subsubsection{Percepção dos usuários quanto à segurança}

Abaixo apresenta-se a tabela com as afirmações disponibilizadas aos usuários nos questionários da vertente percepção quanto à segurança, a média das notas atribuídas, a nota máxima apresentada, a menor nota atribuída a cada questão e finalmente a nota mais freqüente - moda. 


\begin{tabular}{|c|c|c|c|c|}
\hline QUESTÃO & $\begin{array}{l}\text { MÉDIA DAS } \\
\text { NOTAS }\end{array}$ & $\begin{array}{c}\text { NOTA } \\
\text { MÁXIMA }\end{array}$ & $\begin{array}{c}\text { NOTA } \\
\text { MÍNIMA }\end{array}$ & MODA \\
\hline $\begin{array}{l}\text { O comportamento dos servidores dos } \\
\text { órgãos julgadores do STJ inspiram } \\
\text { confiança em você. }\end{array}$ & 6,13 & 7 & 1 & 7 \\
\hline $\begin{array}{l}\text { Você se sente seguro em suas utilizações } \\
\text { do serviço dos órgãos julgadores do STJ. }\end{array}$ & 6,10 & 7 & 3 & 7 \\
\hline $\begin{array}{l}\text { Os servidores dos órgãos julgadores do } \\
\text { STJ são realmente gentis com você }\end{array}$ & 6,07 & 7 & 1 & 7 \\
\hline Os servidores dos órgãos do STJ & & & & \\
\hline $\begin{array}{l}\text { compreendem suas necessidades } \\
\text { específicas }\end{array}$ & 5,87 & 7 & 1 & 7 e 6 \\
\hline
\end{tabular}

Tabela 15: Percepção dos usuários - dimensão segurança.

A dimensão segurança é a que possui a melhor percepção por parte dos usuários dos serviços da Secretaria dos Órgãos Julgadores. Essa afirmação pode ser feita com base nas médias das notas atribuídas a cada uma das afirmativas que avaliam a dimensão - três das quatro questões que avaliam aspectos da dimensão receberam nota superior a 6,07.

Somente a afirmação que avalia se os servidores responsáveis pelo atendimento compreendem suas necessidades específicas que recebeu a nota 5,87. Sendo que também foi a única sentença onde as notas 6 e 7 empataram em número de ocorrências. Um dado importante também é que a diferença entre a maior média de expectativa e essa menor é de apenas 0,26 pontos da escala de valor.

Essa realidade nos permite afirmar também que os usuários dos serviços da SOJ sentem-se seguros quanto aos serviços prestados.

\subsubsection{GAP da dimensão segurança}

A partir da análise das médias de cada questão analisa-se a diferença entre as expectativas dos usuários e a percepção deles em relação aos serviços prestados pela Secretaria dos Órgãos Julgadores, que se denomina GAP da qualidade.

Abaixo se segue uma tabela que mostra o GAP de cada afirmativa e o GAP final da dimensão segurança. 


\begin{tabular}{lccc}
\hline \multicolumn{1}{c}{ ITEM } & EXPECTATIVA & PERCEPÇÃO & GAP \\
\hline $\begin{array}{l}\text { Segurança no comportamento dos } \\
\text { servidores }\end{array}$ & 6,51 & 6,13 & 0,38 \\
Segurança na utilização dos serviços & 6,49 & 6,10 & 0,39 \\
Real gentileza dos servidores & 6,29 & 6,07 & 0,22 \\
Compreensão das necessidades & 6,00 & 5,87 & 0,13 \\
individuais dos usuários & & 6,32 & 0,27
\end{tabular}

Tabela 16: GAPs - dimensão segurança.

A análise global da dimensão segurança, que se dá com o cálculo dos gaps de cada afirmação e o gap final da dimensão, nos permite afirmar que os usuários dos serviços da Secretaria dos Órgão Julgadores do STJ têm segurança nos serviços prestados. O gap total da dimensão finalizou em apenas 0,27 pontos na escala de valor proposta.

Os maiores hiatos apresentaram-se em relação à segurança no comportamento dos servidores $(0,38)$ e em relação à segurança na utilização dos serviços $(0,39)$. Os números são os mais altos dentro da dimensão estudada, todavia são pequenos em relação à escala de valor utilizada (0 a 7). Esse fator não compromete a segurança que os usuários têm em relação à prestação do serviço, entretanto não dispensa atenção dos responsáveis das unidades de atendimento para que com pequenas adequações a percepção dos usuários seja equiparada a sua expectativa.

As percepções dos usuários quanto a real gentileza dos servidores e a compreensão das necessidades individuais praticamente não destoam das expectativas apresentadas, com números de 0,22 e 0,13 respectivamente. Porém, sempre é possível melhorar.

\subsection{Dimensão 5: empatia}

Para entender a dimensão empatia é preciso mensurar o grau de cuidado e atenção esperado e percebido pelos usuários dos serviços.

\subsubsection{Expectativa dos usuários quanto à empatia}

Abaixo se apresenta a tabela com as afirmações disponibilizadas aos usuários nos questionários da vertente expectativa, a média das notas atribuídas, a nota máxima apresentada, a menor nota atribuída a cada questão e finalmente a nota mais freqüente. 


\begin{tabular}{|c|c|c|c|c|}
\hline QUESTÃO & $\begin{array}{l}\text { MÉDIA DAS } \\
\text { NOTAS }\end{array}$ & $\begin{array}{c}\text { NOTA } \\
\text { MÁXIMA }\end{array}$ & $\begin{array}{c}\text { NOTA } \\
\text { MÍNIMA }\end{array}$ & MODA \\
\hline $\begin{array}{l}\text { Um serviço prestado por um órgão } \\
\text { judicante deveria dar atenção individual } \\
\text { ao usuário }\end{array}$ & 5,77 & 7 & 1 & 7 \\
\hline $\begin{array}{l}\text { Os servidores de um órgão judicante } \\
\text { deveriam dar atenção individualizada aos } \\
\text { usuários }\end{array}$ & 5,88 & 7 & 2 & 7 \\
\hline $\begin{array}{l}\text { Um órgão judicante deveria levar a sério } \\
\text { os interesses mais importantes do usuário }\end{array}$ & 6,38 & 7 & 2 & 7 \\
\hline $\begin{array}{l}\text { Um órgão judicante deveria ter horário de } \\
\text { atendimento conveniente }\end{array}$ & 6,44 & 7 & 2 & 7 \\
\hline
\end{tabular}

Tabela 17: Expectativas dos usuários - dimensão empatia.

Os dados apresentados na vertente expectativa, da dimensão empatia, permite mais uma vez afirmar que as expectativas dos usuários dos quanto aos serviços prestados por um órgão judicante é alta. Essa afirmativa é embasada, principalmente, pela nota máxima apresentada (7) em todas as questões. Essa nota também é a mais freqüente em todas as afirmativas.

Entre as médias das notas obtidas, a sentença que avalia a expectativa do usuário quanto à conveniência dos horários de atendimento (Um órgão judicante deveria ter horário de atendimento conveniente) é a que obteve a maior média $(6,44)$. Isso nos mostra que os usuários têm alta expectativa quanto à possibilidade de contar com um horário de atendimento que seja adequado a sua rotina de trabalho.

Os usuários consideraram a atenção individualizada como o aspecto menos importante avaliado dentro da dimensão, com a média de 5,77. A afirmativa proposta no questionário foi: “Um serviço prestado por um órgão judicante deveria dar atenção individual ao usuário”. A afirmativa seguinte, que também avaliava questões da atenção individualizada recebeu a segunda nota mais baixa - 5,88. É salutar dizer que essa mensuração entre baixa e alta é dentro da dimensão, o que não nos permite afirmar que os usuários não querem uma atenção individualizada quando procuram os serviços de um órgão judicante.

\subsubsection{Percepção dos usuários quanto à empatia}

Abaixo se apresenta a tabela com as afirmações disponibilizadas aos usuários nos questionários da vertente percepção, a média das notas atribuídas, a nota máxima apresentada, a menor nota atribuída a cada questão e finalmente a moda. 


\begin{tabular}{|c|c|c|c|c|}
\hline QUESTÃO & $\begin{array}{l}\text { MÉDIA DAS } \\
\text { NOTAS }\end{array}$ & $\begin{array}{c}\text { NOTA } \\
\text { MÁXIMA }\end{array}$ & $\begin{array}{c}\text { NOTA } \\
\text { MÍNIMA }\end{array}$ & MODA \\
\hline $\begin{array}{l}\text { Os órgãos julgadores do STJ dão atenção } \\
\text { individual ao usuário }\end{array}$ & 5,70 & 7 & 2 & 6 \\
\hline $\begin{array}{l}\text { Os servidores dos órgãos julgadores do } \\
\text { STJ dão atenção individualizada a você } \\
\text { enquanto usuário dos serviços prestados }\end{array}$ & 5,82 & 7 & 2 & 7 \\
\hline $\begin{array}{l}\text { Os órgãos julgadores do STJ levam os } \\
\text { interesses mais importantes do usuário a } \\
\text { sério }\end{array}$ & 6,01 & 7 & 3 & 7 \\
\hline $\begin{array}{l}\text { Os órgãos julgadores do STJ possuem } \\
\text { horário de atendimento conveniente }\end{array}$ & 6,39 & 7 & 4 & 6 \\
\hline
\end{tabular}

Tabela 18: Percepção dos usuários - dimensão empatia.

A primeira afirmativa da vertente percepção (os órgãos julgadores do STJ dão atenção individual ao usuário) obteve como média 5,70. Essa foi menor nota da dimensão quanto à percepção dos usuários. A segunda menor nota atribuída pelos usuários foi na afirmativa “os servidores dos órgãos julgadores do STJ dão atenção individualizada a você enquanto usuário dos serviços prestados”, com a média 5,82. Esses números mostram que os usuários não percebem uma total atenção individualizada quando procuram um serviço nas unidades de atendimento da Secretaria dos Órgãos Julgadores.

A maior nota recebida na dimensão quanto à percepção foi na afirmativa "Os órgãos julgadores do STJ possuem horário de atendimento conveniente”, com a média de 6,39. Se comparar a média recebida com a nota mais freqüente apresentada na afirmativa é possível constatar que houve pouca variação nas notas recebidas pela afirmativa, conseqüentemente se infere que a maior parte dos usuários tem a mesma percepção sobre o item avaliado, ou seja, que o horário de atendimento da Secretaria dos Órgãos julgadores é conveniente.

A afirmação “os órgãos julgadores do STJ levam os interesses mais importantes do usuário a sério” obteve uma média de 6,01. Dentre as percepções apresentadas pelos usuários na dimensão empatia, essa foi a afirmação com a segunda maior média.

\subsubsection{GAP da dimensão empatia}

A partir da análise das médias de cada questão analisa-se a diferença entre as expectativas dos usuários e a percepção deles em relação aos serviços prestados pela Secretaria dos Órgãos Julgadores, que se denomina GAP da qualidade. 
Abaixo segue uma tabela que mostra o GAP de cada afirmativa e o GAP final da dimensão empatia.

\begin{tabular}{lccc}
\hline \multicolumn{1}{c}{ ITEM } & EXPECTATIVA & PERCEPÇÃO & GAP \\
\hline $\begin{array}{l}\text { É institucional a atenção individual ao } \\
\text { usuário }\end{array}$ & 5,77 & 5,70 & 0,07 \\
$\begin{array}{l}\text { Os servidores prestam uma atenção } \\
\text { individual ao usuário }\end{array}$ & 5,88 & 5,82 & 0,06 \\
$\begin{array}{l}\text { A instituição considera os interesses dos } \\
\text { usuários }\end{array}$ & 6,38 & 6,01 & 0,37 \\
Conveniência do horário de atendimento & 6,44 & 6,05 \\
\hline GAP TOTAL & 6,12 & 5,98 & 0,14
\end{tabular}

Tabela 19: GAPs - dimensão empatia.

Os serviços prestados pela Secretaria dos Órgãos Julgadores do Superior Tribunal de Justiça atendem quase que plenamente as expectativas de seus usuários dentro da dimensão empatia. Essa afirmativa é subsidiada pelo número final do gap calculado na dimensão que foi de apenas 0,14 pontos da escala de valor.

O maior hiato que se evidenciou na dimensão foi referente a consideração que a instituição tem com os interesses dos usuários. Todavia, apesar de maior, o número é pouco expressivo totalizando apenas 0,37 pontos.

Os gaps das demais afirmativas ficaram entre 0,07 e 0,05 pontos da escala de valor. Assim, podemos considerar que a percepção do serviço prestado é igual a expectativa apresentada pelos usuários.

\subsection{GAP Total das 5 dimensões - o gap da qualidade do serviço}

Nas cinco últimas subseções do trabalho desconstruímos o objeto para analisar suas partes e fazer as devidas considerações sobre cada uma delas.

Nesta parte realizaremos a análise final da qualidade do serviço, baseando-se nos cálculos e afirmações já elencadas nos capítulos anteriores, de forma a reconstruir o objeto e analisá-lo como um todo.

Abaixo se apresenta uma tabela condensada com as médias e gaps de cada dimensão da qualidade e ao final o gap total da qualidade dos serviços prestados pela Secretaria dos Órgãos Julgadores do Superior Tribunal de Justiça. 


\begin{tabular}{lccc}
\hline \multicolumn{1}{c}{ DIMENSÃO } & SERVIÇO ESPERADO & SERVIÇO PERCEBIDO & HIATO \\
\hline Aspectos Tangíveis & $\mathbf{6 , 1 2}$ & 5,64 & $\mathbf{0 , 4 8}$ \\
Confiabilidade & 6,52 & 5,79 & 0,73 \\
Presteza & 6,32 & 5,82 & 0,50 \\
Segurança & 6,32 & 6,05 & 0,27 \\
Empatia & 6,12 & 5,98 & 0,14 \\
\hline \multicolumn{1}{c}{ GAP DA QUALIDADE } & 6,28 & 5,86 & 0,42 \\
\hline \multicolumn{1}{c}{ PRESTADOS } & & & \\
\hline
\end{tabular}

Tabela 20: Totalização do GAP da qualidade no serviço prestado.

Partindo dos dados já analisados e do GAP da qualidade dos serviços prestados pela Secretaria dos Órgãos Julgadores, apresentado na tabela acima, é possível afirmar que temos uma boa qualidade na prestação dos serviços na visão dos usuários. Todavia, ainda existem pontos em cada dimensão da qualidade que precisam ser analisados para que as diferenças entre as expectativas e a percepção detectadas pela pesquisa - 0,42 pontos da escala de valor sejam completamente sanadas.

A análise da pesquisa nos diz também que pouco falta para se atinja a excelência na qualidade dos serviços prestados pela SOJ, e justamente por isso seria importante a atenção dos administradores do serviço para essas pequenas questões.

É relevante refletir ainda que em nenhum item individual e, por conseguinte, em nenhuma dimensão, a SOJ superou as expectativas dos usuários - ou seja a os serviços prestados estão sempre aquém das necessidades e expectativas apresentadas pelos usuários.

A dimensão que mais precisa ser trabalhada é a da confiabilidade, seguida da dimensão presteza e da dimensão aspectos tangíveis. Os hiatos mostrados nas dimensões segurança e empatia podem ser neutralizados com a devida atenção aos três primeiros gaps. 


\section{CONCLUSÃO}

Coutinho (2000) define qualidade como a maximização do sucesso do cliente. Isso quer dizer: o cliente considera um serviço de qualidade quando suas necessidades são atendidas, ou seja, o sucesso é atingido.

O autor defende ainda que para esse sucesso ser atingido, é preciso que o prestador do serviço preocupe-se com as relações interdependentes que permeiam a prestação de serviços. Relações essas baseadas na parceria e na cooperação. E além, que cada unidade da organização deve visar sempre à qualidade do seu trabalho para que isso possa produzir um bom desempenho da organização como um todo.

É salutar dizer que, a rigor, os padrões de bons serviços aos cidadãos devem ser obtidos com os próprios usuários, verificando o que desejam. Portanto, passa a ser crucial a realização de pesquisas junto aos cidadãos-usuários, de forma a obter informações a respeito de suas necessidades, bem como sobre formas de melhorar o atendimento. (BRESSERPEREIRA, 1998)

Diante dessa realidade, este trabalho teve como objetivo mensurar a percepção dos usuários dos serviços da Secretaria dos Órgãos Julgadores do Superior Tribunal de Justiça quanto à qualidade, confiabilidade, presteza e segurança dos serviços prestados. Escolheu-se o instrumento SERVQUAL (PARASURAMAN et al, apud ABACKERLI et al, 2005) para a realização da pesquisa apresentada neste trabalho. O instrumento foi mobilizado na tentativa de mensurar as expectativas dos usuários em relação aos serviços prestados pela Secretaria dos Órgãos Julgadores do Superior Tribunal de Justiça e, em seguida, a sua percepção quanto ao serviço efetivamente prestado. Desta forma, estaria viabilizada a análise dos gaps de qualidade, tal como discutidos em nosso referencial teórico.

A análise dos dados nos fez considerar que os serviços são prestados de forma satisfatória, contudo algumas aspectos ainda precisam de atenção, por parte dos administradores dos serviços, para que seja atingida a excelência esperada pelo cidadão nos serviços.

Entre os pontos a serem vistos, dentro de cada dimensão da qualidade avaliada, estão:

- Aspectos Tangíveis: melhorar as instalações físicas e atualização de softwares e equipamento que possibilitam o acesso remoto aos serviços oferecidos pela Secretaria dos Órgãos Julgadores, principalmente o processo digital, que auxiliará no decréscimo do número de atendimentos presenciais prestados pela SOJ, aumentando a disponibilidade de servidores para a execução de outros serviços. 
- Confiabilidade: honrar o cumprimento dos prazos acordados com os usuários para entrega e execução de um serviço; solucionar de forma mais rápida e eficaz os problemas apresentados pelos usuários; e acabar com processos de retrabalho gerados por serviços executados de forma incorreta, pois qualquer atraso ou descumprimento de acordos podem gerar prejuízos irreparáveis para o cidadão e a sociedade.

- Presteza: reduzir o tempo de espera dos usuários no momento do atendimento nas unidades da SOJ; aumentar a disponibilidade dos servidores (servidores menos sobrecarregados poderão atender mais rapidamente os pedidos dos usuários).

- Segurança: treinar os servidores da "linha de frente” para que transmitam mais segurança aos usuários no momento do atendimento; aumentar os controles de acesso aos serviços oferecidos de forma remota para que os usuários sintam-se mais seguros quando buscarem determinado serviço.

- Empatia: escutar e viabilizar os interesses individuais e coletivos dos usuários dos serviços para implantar ou aperfeiçoar uma rotina.

É importante ressaltar que as expectativas e percepções sobre a qualidade do serviço prestado por um órgão judicante podem mudar ao longo do tempo. Naturalmente as demandas dos usuários mudarão com a evolução social, bem como com a entrada de novas normas no ordenamento jurídico, a adoção de novas tecnologias, dentre outras. O fato de não ter superado as expectativas dos usuários em nenhuma das dimensões da qualidade avaliadas nos faz afirmar que os administradores públicos devem estar atentos a essas novas necessidades e esperanças vindos da sociedade, para que assim, possam atendê-las de forma plena (e quem sabe superá-las), colaborando para o aumento do bem-estar social. 


\section{REFERÊNCIAS}

ABACKERLI, A. J.; MIGUEL, P. A. C.; SALOMI, G. G. E. Servqual X Servperf: comparação entre instrumentos para avaliação da qualidade em serviços internos. Gestão \& Produção. São Paulo, v. 12, n. 2, p. 279-293, mai./ago. 2005.

ABRUCIO, Fernando Luiz. O impacto do modelo gerencial na administração pública: um breve estudo sobre a experiência internacional recente. Cadernos ENAP; $n^{0} 10$. 1997.

ARAGÃO, Cecília Vescovi de. Burocracia, eficiência e modelos de gestão pública: um ensaio. Revista do Serviço Público. ENAP: ano 48, número 3, set-dez, 1997.

BANDEIRA DE MELO, C. A. Curso de direito administrativo. 12.ed. São Paulo: Malheiros, 1999.

BRASIL. Superior Tribunal de Justiça (STJ). Antecedentes históricos do Superior de Justiça. Brasília: Superior Tribunal de Justiça, 1989.

BRASIL. Superior Tribunal de Justiça (STJ). Planejamento Estratégico - Plano de Gestão 2006/2008. Brasília. Superior Tribunal de Justiça, 2006.

BRESSER-PEREIRA, Luiz Carlos. Estratégia e estrutura para um novo Estado. Revista do Serviço Público. ENAP: ano 48, número 1, jan-abr, 1997.

BRESSER-PEREIRA, Luiz Carlos. Uma reforma gerencial da administração pública no Brasil. Revista do Serviço Público. ENAP: ano 49, número 1, jan-mar, 1998.

CARVALHO, Marly Monteiro; PALADINI, Edson Pacheco (coord.). Gestão da qualidade: teoria e casos. Rio de Janeiro: Elsevier, 2005.

COUTINHO, Marcelo James Vasconcelos. A administração pública voltada para o cidadão: quadro teórico-conceitual. Revista do Serviço Público. ENAP: Ano 51, número 3, jul-set 2000.

CUNHA, Carlos Mendes da Silveira. O Conceito de Serviço Público: O caso do serviço público postal e a era digital. Clubjus, Brasília-DF: 24 jul. 2008. Disponível em: $<$ http://www.clubjus.com.br/cbjur.php?artigos\&ver=2.19950>. Acesso em: 19 ago. 2008.

DEMING, W. Edwards. Qualidade: a revolução da administração. Tradução de Clave Comunicações e Recursos Humanos. Rio de Janeiro: Marques-Saraiva, 1990.

DI PIETRO, M. S. Z. Direito Administrativo. 11.ed. São Paulo: Atlas, 1999.

FAORO, Raymundo. Os donos do poder: formação do patronato político brasileiro. 3.ed. São Paulo: Globo, 2001.

FITZSIMMONS, James A.; FITZSIMMONS, Mona J. Administração de serviços: operações, estratégia e tecnologia da informação. 4. ed. Porto Alegre: Bookman, 2005. 
FAUSTO, Boris. História Concisa do Brasil. 2.ed. São Paulo: Editora da Universidade de São Paulo, 2006.

GILBERT, G. Ronald; NOCHOLLS, J. A. F. e ROSLOW, Sydney. A mensuração da satisfação dos clientes do setor público. Revista do Serviço Público. ENAP: Ano 51, número 3, jul-set 2000.

GONÇALVES, Hortência de Abreu. Manual de metodología da pesquisa científica. São Paulo: Avercamp, 2005.

GRÖNROOS, Christian. Marketing, gerenciamento e serviços, Editora Campus, São Paulo, 1993

MACIEL, Alba Regina. Conceito de Serviço Público. Bate Byte, Curitiba-PR: Ago. 2002. Disponível em:

<http://www.pr.gov.br/batebyte/edicoes/2002/bb123/conceito.htm>. Acesso em: 05 ago. 2008.

MARTINS, Humberto Falcão. Burocracia e a revolução gerencial - a persistência da dicotomia entre política e administração. Revista do Serviço Público. ENAP: ano 48, número 1, jan-abr, 1997.

MEIRELLES, H. L. Direito administrativo brasileiro. 25.ed. São Paulo: Malheiros, 1999.

MOREIRA NETO, D. F. Mutações do direito administrativo. Rio de Janeiro: Renovar, 2000.

PARASURAMAN, A; ZEITHAML, V.; BERRY, L. SERVQUAL: a multiple-item scale for measuring consumer perceptions of service quality. Journal of Retailing, v.64, spring, p.12-40, 1988.

PAULA, Ana Paula Paes de. Por uma nova gestão pública: limites e potencialidades da experiência contemporânea. Reimpressão. Rio de Janeiro: Editora FGV, 2007.

VERGARA, Sylvia Constant. Métodos de pesquisa em administração. $2^{\mathrm{a}}$ Ed. São Paulo: Atlas, 2006. 
ANEXO I 


\section{O instrumento Servqual - modelo de aplicação - Expectativas}

Esta pesquisa aborda sua opinião sobre os serviços prestados pelos órgãos judicantes do Superior Tribunal de Justiça. Por favor, indique o grau que você acha que os prestadores dos serviços das áreas judicantes do STJ deveriam apresentar das características descritas em cada enunciado. Faça isso assinalando um dos sete números após cada enunciado. Se você concorda plenamente que esses prestadores de serviços deveriam ter determinada característica, assinale o número 7. Se você discorda totalmente que essas empresas deveriam possuir essa característica, assinale o número 1 . Em situações intermediárias, assinale um número entre 2 e 6, de acordo com seu grau de concordância com o enunciado. Não há respostas certas ou erradas - estamos interessados no número que melhor represente as suas expectativas sobre as instituições do Poder Judiciário que oferecem serviços em seus órgãos judicantes.

\begin{tabular}{|c|c|c|c|c|c|c|c|}
\hline \multirow{2}{*}{$\begin{array}{l}\text { Questões } \\
\text { Um serviço de prestação jurisdicional deveria contar com equipamentos modernos que possibilitassem } \\
\text { auto-atendimento e atendimento remoto aos seus usuários. }\end{array}$} & \multicolumn{5}{|c|}{$\begin{array}{l}\text { Discordo } \\
\text { Totalmente }\end{array}$} & \multicolumn{2}{|c|}{$\begin{array}{l}\text { Concordo } \\
\text { Plenamente }\end{array}$} \\
\hline & $\square 1$ & $\square 2$ & $\square 3$ & $\square 4$ & $\square 5$ & $\square 6$ & $\square 7$ \\
\hline Quando um serviço judicante promete fazer algo em certo tempo, deveria fazê-lo. & $\square 1$ & $\square 2$ & $\square 3$ & $\square 4$ & $\square 5$ & $\square 6$ & $\square 7$ \\
\hline $\begin{array}{l}\text { Os servidores de um órgão judicante deveriam prestar serviços prontamente, de modo que seus } \\
\text { usuários esperem pelo serviço o menor tempo possível. }\end{array}$ & $\square 1$ & $\square 2$ & $\square 3$ & $\square 4$ & $\square 5$ & $\square 6$ & $\square 7$ \\
\hline O comportamento dos servidores de um órgão judicante do STJ deveria inspirar confiança em você. & $\square 1$ & $\square 2$ & $\square 3$ & $\square 4$ & $\square 5$ & $\square 6$ & $\square 7$ \\
\hline Um serviço prestado por um órgão judicante deveria dar atenção individual ao usuário. & $\square 1$ & $\square 2$ & $\square 3$ & $\square 4$ & $\square 5$ & $\square 6$ & $\square 7$ \\
\hline As instalações físicas de um órgão judicante deveriam ser visualmente atrativas. & $\square 1$ & $\square 2$ & $\square 3$ & $\square 4$ & $\square 5$ & $\square 6$ & $\square 7$ \\
\hline $\begin{array}{l}\text { Quando os usuários de um órgão judicante têm algum problema, os responsáveis pelo serviço deveriam } \\
\text { mostrar interesse sincero em resolvê-lo. }\end{array}$ & $\square 1$ & $\square 2$ & $\square 3$ & $\square 4$ & $\square 5$ & $\square 6$ & $\square 7$ \\
\hline Os servidores de um órgão judicante deveriam prestar serviços prontamente. & $\square 1$ & $\square 2$ & $\square 3$ & $\square 4$ & $\square 5$ & $\square 6$ & $\square 7$ \\
\hline Você deveria se sentir seguro em suas utilizações do serviço de um órgão judicante. & $\square 1$ & $\square 2$ & $\square 3$ & $\square 4$ & $\square 5$ & $\square 6$ & $\square 7$ \\
\hline Os servidores de um órgão judicante deveriam dar atenção individualizada aos usuários. & $\square 1$ & $\square 2$ & $\square 3$ & $\square 4$ & $\square 5$ & $\square 6$ & $\square 7$ \\
\hline Os servidores de um órgão judicante deveriam estar bem vestidos e cuidar de sua aparência. & $\square 1$ & $\square 2$ & $\square 3$ & $\square 4$ & $\square 5$ & $\square 6$ & $\square 7$ \\
\hline $\begin{array}{l}\text { Um serviço de um órgão judicante deveria ser executado corretamente já na primeira vez, evitando } \\
\text { assim o retorno de seus usuários para a correção de algum serviço prestado. }\end{array}$ & $\square 1$ & $\square 2$ & $\square 3$ & $\square 4$ & $\square 5$ & $\square 6$ & $\square 7$ \\
\hline $\begin{array}{l}\text { Os servidores de um órgão judicante nunca devem estar demasiadamente ocupados para atender uma } \\
\text { solicitação. }\end{array}$ & $\square 1$ & $\square 2$ & $\square 3$ & $\square 4$ & $\square 5$ & $\square 6$ & $\square 7$ \\
\hline Os servidores de um órgão judicante deveriam ser realmente gentis com você. & $\square 1$ & $\square 2$ & $\square 3$ & $\square 4$ & $\square 5$ & $\square 6$ & $\square 7$ \\
\hline Um órgão judicante deveria levar a sério os interesses mais importantes do usuário. & $\square 1$ & $\square 2$ & $\square 3$ & $\square 4$ & $\square 5$ & $\square 6$ & $\square 7$ \\
\hline $\begin{array}{l}\text { Os materiais associados a um serviço prestado por um órgão judicante (como folhetos explicativos) } \\
\text { deveriam possuir apelo visual. }\end{array}$ & $\square 1$ & $\square 2$ & $\square 3$ & $\square 4$ & $\square 5$ & $\square 6$ & $\square 7$ \\
\hline Um órgão judicante deveria fornecer o serviço requerido pelo usuário no tempo prometido. & $\square 1$ & $\square 2$ & $\square 3$ & $\square 4$ & $\square 5$ & $\square 6$ & $\square 7$ \\
\hline $\begin{array}{l}\text { Os servidores de um órgão judicante deveriam ter o conhecimento necessário para responder seus } \\
\text { questionamentos. }\end{array}$ & $\square 1$ & $\square 2$ & $\square 3$ & $\square 4$ & $\square 5$ & $\square 6$ & $\square 7$ \\
\hline Os servidores de um órgão judicante deveriam compreender as suas necessidades específicas. & $\square 1$ & $\square 2$ & $\square 3$ & $\square 4$ & $\square 5$ & $\square 6$ & $\square 7$ \\
\hline Um órgão judicante deveria ter horário de atendimento conveniente. & $\square 1$ & $\square 2$ & $\square 3$ & $\square 4$ & $\square 5$ & $\square 6$ & $\square 7$ \\
\hline $\begin{array}{l}\text { Um órgão judicante deveria manter seus usuários informados acerca de quando os serviços serão } \\
\text { executados. }\end{array}$ & $\square 1$ & $\square 2$ & $\square 3$ & $\square 4$ & $\square 5$ & $\square 6$ & $\square 7$ \\
\hline
\end{tabular}




\section{O instrumento Servqual - modelo de aplicação - Percepção}

Os enunciados a seguir relacionam-se às suas impressões sobre os serviços prestados pelos órgãos judicantes do Superior Tribunal de Justiça. Para cada enunciado, por favor diga em que grau você acredita que os serviços prestados pelos órgãos judicantes do Superior Tribunal de Justiça do STJ tem a característica descrita pelo enunciado. Novamente, assinale 7 se você concorda inteiramente que os serviços prestados pelos órgãos judicantes do STJ apresentam aquela característica, e assinale 1 se você discorda totalmente. Você pode assinalar qualquer um dos números intermediários que indique o seu grau de concordância. Não há respostas certas ou erradas - estamos interessados apenas no número que melhor represente suas percepções sobre os serviços prestados pelos órgãos judicantes do Superior Tribunal de Justiça STJ.

\begin{tabular}{|c|c|c|c|c|c|c|c|}
\hline \multirow{2}{*}{$\begin{array}{l}\text { Questões } \\
\text { O serviço prestado pelos órgãos julgadores do STJ utiliza equipamentos modernos que possibilitam o } \\
\text { auto-atendimento e atendimento remoto aos seus usuários.. }\end{array}$} & \multicolumn{5}{|c|}{$\begin{array}{l}\text { Discordo } \\
\text { Totalmente }\end{array}$} & \multicolumn{2}{|c|}{$\begin{array}{l}\text { Concordo } \\
\text { Plenamente }\end{array}$} \\
\hline & $\square 1$ & $\square 2$ & $\square 3$ & $\square 4$ & $\square 5$ & $\square 6$ & $\square 7$ \\
\hline Quando um órgão julgador do STJ promete fazer algo em certo tempo, realmente o faz. & $\square 1$ & $\square 2$ & $\square 3$ & $\square 4$ & $\square 5$ & $\square 6$ & $\square 7$ \\
\hline $\begin{array}{l}\text { Os servidores dos órgãos julgadores do STJ prestam serviços prontamente de modo que seus usuários } \\
\text { esperem pelo serviço o menor tempo possível. }\end{array}$ & $\square 1$ & $\square 2$ & $\square 3$ & $\square 4$ & $\square 5$ & $\square 6$ & $\square 7$ \\
\hline O comportamento dos servidores dos órgãos julgadores do STJ inspiram confiança em você. & $\square 1$ & $\square 2$ & $\square 3$ & $\square 4$ & $\square 5$ & $\square 6$ & $\square 7$ \\
\hline Os órgãos julgadores do STJ dão atenção individual ao usuário. & $\square 1$ & $\square 2$ & $\square 3$ & $\square 4$ & $\square 5$ & $\square 6$ & $\square 7$ \\
\hline As instalações físicas dos órgãos julgadores do STJ são visualmente atrativas. & $\square 1$ & $\square 2$ & $\square 3$ & $\square 4$ & $\square 5$ & $\square 6$ & $\square 7$ \\
\hline $\begin{array}{l}\text { Quando o usuário dos órgãos julgadores do STJ tem algum problema, os responsáveis pelo serviço } \\
\text { mostram interesse sincero em resolvê-lo. }\end{array}$ & $\square 1$ & $\square 2$ & $\square 3$ & $\square 4$ & $\square 5$ & $\square 6$ & $\square 7$ \\
\hline Os servidores dos órgãos julgadores do STJ estão sempre dispostos a ajudá-lo. & $\square 1$ & $\square 2$ & $\square 3$ & $\square 4$ & $\square 5$ & $\square 6$ & $\square 7$ \\
\hline Você se sente seguro em suas utilizações do serviço dos órgãos julgadores do STJ. & $\square 1$ & $\square 2$ & $\square 3$ & $\square 4$ & $\square 5$ & $\square 6$ & $\square 7$ \\
\hline $\begin{array}{l}\text { Os servidores dos órgãos julgadores do STJ dão atenção individualizada a você enquanto usuário dos } \\
\text { serviços prestados. }\end{array}$ & $\square 1$ & $\square 2$ & $\square 3$ & $\square 4$ & $\square 5$ & $\square 6$ & $\square 7$ \\
\hline Os servidores dos órgãos julgadores do STJ são bem vestidos e cuidam de sua aparência. & $\square 1$ & $\square 2$ & $\square 3$ & $\square 4$ & $\square 5$ & $\square 6$ & $\square 7$ \\
\hline $\begin{array}{l}\text { Os serviços dos órgãos julgadores do STJ são executados corretamente já na primeira vez, evitando } \\
\text { assim que seu retorno para corrigir o serviço prestado. }\end{array}$ & $\square 1$ & $\square 2$ & $\square 3$ & $\square 4$ & $\square 5$ & $\square 6$ & $\square 7$ \\
\hline $\begin{array}{l}\text { Os servidores dos órgãos julgadores do STJ nunca estão demasiadamente ocupados para atender sua } \\
\text { solicitação. }\end{array}$ & $\square 1$ & $\square 2$ & $\square 3$ & $\square 4$ & $\square 5$ & $\square 6$ & $\square 7$ \\
\hline Os servidores dos órgãos julgadores do STJ são realmente gentis com você. & $\square 1$ & $\square 2$ & $\square 3$ & $\square 4$ & $\square 5$ & $\square 6$ & $\square 7$ \\
\hline Os órgãos julgadores do STJ levam os interesses mais importantes do usuário a sério. & $\square 1$ & $\square 2$ & $\square 3$ & $\square 4$ & $\square 5$ & $\square 6$ & $\square 7$ \\
\hline $\begin{array}{l}\text { Os materiais associados aos órgãos julgadores do STJ (como folhetos explicativos) possuem boa } \\
\text { comunicação e apelo visual. }\end{array}$ & $\square 1$ & $\square 2$ & $\square 3$ & $\square 4$ & $\square 5$ & $\square 6$ & $\square 7$ \\
\hline Os órgãos julgadores do STJ fornecem o serviço no tempo prometido. & $\square 1$ & $\square 2$ & $\square 3$ & $\square 4$ & $\square 5$ & $\square 6$ & $\square 7$ \\
\hline $\begin{array}{l}\text { Os servidores dos órgãos julgadores do STJ têm o conhecimento necessário para responder seus } \\
\text { questionamentos. }\end{array}$ & $\square 1$ & $\square 2$ & $\square 3$ & $\square 4$ & $\square 5$ & $\square 6$ & $\square 7$ \\
\hline Os servidores dos órgãos do STJ compreendem suas necessidades específicas. & $\square 1$ & $\square 2$ & $\square 3$ & $\square 4$ & $\square 5$ & $\square 6$ & $\square 7$ \\
\hline Os órgãos julgadores do STJ possuem horário de atendimento conveniente. & $\square 1$ & $\square 2$ & $\square 3$ & $\square 4$ & $\square 5$ & $\square 6$ & $\square 7$ \\
\hline $\begin{array}{l}\text { Os órgãos julgadores do STJ mantêm seus usuários informados acerca de quando os serviços serão } \\
\text { executados. }\end{array}$ & $\square 1$ & $\square 2$ & $\square 3$ & $\square 4$ & $\square 5$ & $\square 6$ & $\square 7$ \\
\hline
\end{tabular}

